\title{
Local traditional ecological knowledge about hay management practices in wetlands of the Biebrza Valley, Poland
}

\author{
Joanna Sucholas ${ }^{1,2^{*}}, Z^{\text {Zsolt Molnár }}{ }^{3},{\text { Łukasz } \text { Łuczaj }^{4} \text { and Peter Poschlod }}^{1}$
}

\begin{abstract}
Background: The Biebrza Valley is one of the largest complexes of wetlands (floodplain and percolation mire) and conservation sites in Central Europe. Local communities have managed the area extensively for subsistence and farming purposes for centuries; nonetheless, since the 1960s, hand mowing and livestock grazing have been gradually ceasing due to the intensification of farming, and wetlands have undergone natural succession. Currently, the protection of this vast ecosystem is challenging. Despite its remarkable cultural origin, the complexity of the traditional practices and knowledge of local people have never been studied comprehensively. Therefore, we found it urgent to explore if traditional ecological knowledge that could be used in conservation management of the area still exists among the local community.
\end{abstract}

Methods: We interviewed 42 inhabitants of seven villages located in the Lower Basin of the Biebrza Valley (NEPoland) in the consecutive years 2018-2020. We applied semi-structured, repeated interviews with farmers (aged 29-89), each lasting several hours. By using different ethnoecological methods (visual stimuli, walks in wetlands, co-mapping of the area), we explored traditional knowledge on the plants, landscape and traditional management of wetlands.

Results: Farmers from the oldest generation, who used to manage wetlands with scythes, shared the deepest ecological knowledge. Local people divided wetlands into zones differentiated by vegetation type and hay quality. Depending on plant composition, people managed wetlands under a mixed regime: mowing once or twice a year during periods that ensured good hay quality and pasturing various livestock: cattle, horses, sheep, pigs and fowl. We identified at least 50 plant ethnospecies, which were described exhaustively by their habitat, morphological features, and mowing and grazing value.

Conclusions: The local community in the Biebrza Valley shared a deep traditional ecological knowledge and had a good memory of traditional farming practices. Research confirmed the unquestionable cultural origin of the local ecosystem, therefore in conservation endeavours the area should be treated first and foremost as a cultural landscape. The documented exceptional local perception of the wetland landscape, elements of traditional knowledge and complex farming practices should be considered for inclusion into conservation management, and cooperation with the local community should also be taken into account.

*Correspondence: j.sucholas@gmail.com

${ }^{1}$ Ecology and Conservation Biology, Institute of Plant Sciences, University

of Regensburg, Universitätsstr. 31, 93053 Regensburg, Germany

Full list of author information is available at the end of the article original author(s) and the source, provide a link to the Creative Commons licence, and indicate if changes were made. The images or other third party material in this article are included in the article's Creative Commons licence, unless indicated otherwise in a credit line to the material. If material is not included in the article's Creative Commons licence and your intended use is not permitted by statutory regulation or exceeds the permitted use, you will need to obtain permission directly from the copyright holder. To view a copy of this licence, visit http://creativecommons.org/licenses/by/4.0/. The Creative Commons Public Domain Dedication waiver (http://creativeco mmons.org/publicdomain/zero/1.0/) applies to the data made available in this article, unless otherwise stated in a credit line to the data. 
Keywords: Ethnoecology, Traditional management, Knowledge preservation, Cultural landscape, Conservation area, Lowland river meadows

\section{Introduction}

In the last decades, many studies have revealed the presence of deep knowledge of natural habitats and their management among rural communities in Europe [1-6]. Traditional ecological knowledge (TEK) was previously widely recognised by scientists mainly among indigenous tribal communities outside Europe [7-10] and others. Studies on TEK provide insights into the relationship of local human communities with surrounding nature and into people's understanding of the interactions between elements of nature. TEK evolves throughout the centuries-long life experience of a community within a certain environment and is orally transmitted from generation to generation. TEK incorporates knowledge about elements of the environment, beliefs, ethical values and human practices [11-13] which are the objects of ethnoecological and allied studies [14-16]. However, this knowledge differs in the context of living European rural communities, which were not colonised, derive from the same Judeo-Christian tradition and whose culture was impacted by Roman and Greek heritage. Additionally, it can be influenced by globalisation, agribusiness [17] and education. Molnár [18] defines such traditional ecological knowledge as locally embedded, empirical, 'based upon decades of personal experience with the surrounding landscape, acquired through hands-on management of the landscape, containing centuries-old, communally stored experiences which is mostly independent of western science and connected to rituals of social life. Such knowledge is locally relevant and applicable, therefore we will name it local traditional ecological knowledge (LTEK).

Research shows that European local communitieseither farmers, herders, foresters or fishermen by their traditional practices-have co-created biodiverse habitats, such as high-value grasslands [19-21], and often continue to maintain them [4, 17, 22]. Similarly, the application of traditional practices has led to the development of some wetland types in Europe [23-30]. European wetlands have been traditionally used for grazing, haymaking, hunting, burning, fishing, reed cutting, etc. [31-34]. Owing to that, researchers call for studies in Europe to explore local TEK about landscape, natural resources, land-use practices and their changes, which, when integrated, could help in local conservation and land management endeavours [35]. Moreover, the benefits of such studies for nature conservation are already widely discussed and acknowledged on a global [36-43] and European scale [3, 6, 30, 44-48].
Despite the significant share of human-made and human-managed habitats in Europe [45, 49, 50], cultural landscapes are vanishing, and traditional knowledge and practices are often abandoned [51-56] due to socioeconomical and technical changes of land use, farming intensification, the lack of a traditional managementinclusive policy or the establishment of protected areas that restrict the application of traditional practices. The discontinuation of traditional practices endangers high value habitats and their biodiversity $[46,57]$. In the case of wetlands, the common drainage practice for agricultural intensification is the major threat [24, 58-60] along with natural succession caused by land use abandonment $[32,61]$. First, these processes degrade wetland vegetation and their biodiversity [58, 62, 63]. Second, drainage is the main reason for the eradication of related traditional knowledge, which is no longer implemented [64, 65].

However, even if the traditional farming in Europe is not sustained, it should be feasible to reconstruct it (and the associated knowledge) through the analysis of ecological, archaeological, ethnographic and historical materials $[33,34,51,66]$ or by interviewing local communities, especially the oldest generation, who could still store such knowledge in their memory [35]. The studies show that knowledge might differ according to generation, gender and other variables [67]. In Europe, there are cases of successful nature conservation or restoration by the implementation of traditional practices, for example, the traditional management of subalpine meadows 'Mähder' in Switzerland, supported by a subsidy system [68]; the conservation of meadow orchards 'Strauobstwiesen' in Germany, regulated by local policy [69]; restoration projects of German wetlands [24, 70]; traditionally used floodplains of the Sava River in Lonjsko Polje Nature Park in Croatia [26].

The Biebrza Valley in NE Poland (RAMSAR and NATURA 2000 Site) is one of the largest high value wetlands of cultural origin in Central Europe. The valley is the biggest conservation area of alkaline fens in the EU that needs to be managed to prevent overgrowing [71]. Over centuries, swamps, fens and flooded marshes in the Biebrza Valley were used by peasants for haymaking and grazing. Starting from the 1960s, a part of the wetlands around the Biebrza Valley was drained to facilitate the intensification of agriculture, which caused the retreat of some farmers in the undrained areas [72, 73]. The abandonment of wetland use led to shrub and reed 
encroachment, endangering the biodiverse open wetland habitats [62, 74]. Since the Biebrza National Park was established in 1993, conservationists have been undertaking activities to prevent the succession of vegetation (e.g. shrub removal, mowing with tracked mowers [71, 75]). However, restrictions have been introduced and farming, financially supported by Common Agriculture Policy, has been intensified after the accession of Poland to the EU in 2004. The general frame of wetland management is often defined by EU agri-environmental schemes [76]. All this could eradicate traditional knowledge of local people. Surprisingly, ethnographic studies from the area are scarce $[77,78]$ and only Kiryło [78] described, to some extent, the traditional practices on the wetlands and the locals' knowledge in her ethnobiological Masters thesis. Thus, we recognise an urgent necessity for ethnoecological studies in this area. The study aims to identify what traditional knowledge about wetlands is possessed by the local community living in the Biebrza Valley and to discuss if this knowledge should be used in the management of the nature protection area. For these purposes, the following research questions have been formed:

(1) Is LTEK still present among the local community and how is it distributed?

(2) How do people perceive and value the wetland landscape?

(3) How did they traditionally manage wetlands?

(4) What knowledge do people have about plants occurring in the wetlands?

\section{Methods}

\section{Research area}

The Biebrza National Park located in Podlaskie Province, in NE Poland $\left(53^{\circ} 28^{\prime} 00^{\prime \prime} \mathrm{N}, 22^{\circ} 39^{\prime} 41^{\prime \prime} \mathrm{E}\right)$, with a coverage of ca. $600 \mathrm{~km}^{2}$, protects wetland ecosystems in the Biebrza Valley [71]. The climate in the area is temperate continental, the average annual air temperature is $6.8^{\circ} \mathrm{C}$ and the mean annual precipitation is $583 \mathrm{~mm}$. The area has ca. 200 days of vegetation season [79]. The Biebrza Valley is a large floodplain depression with three distinguishable basins, covered mainly by wetlands $(60 \%)$ with sandy 'islands' (40\%). The valley is supplied by water from regular annual floods of the Biebrza River (extending up to even a few kilometres in width within the Lower Biebrza Basin $[\mathrm{LBB}]$ ) and by groundwater running out from a morainic plateau on the other side of the valley in the direction of the Biebrza River. These hydrogeological conditions caused the development of organic-mineral and muddy soils along the river and peatlands in permanently watered areas [80]. Peatland types are typical floodplain and percolation mires [81].
In historical times, the area was covered by forests [82] with oak, lime and hornbeam on mineral islands and alder, birch and ash trees in swamps. Floodplain mires and marshes by the rivers were areas without trees [83]. Until the fourteenth century, the Biebrza Valley was used extensively and seasonally by hunters, fishermen, cattle herders, haymakers and beekeepers [84]. Permanent settlement started at the end of the fourteenth century, and villages developed on the elevated outskirts of the Biebrza Valley. For centuries, serf peasants used wetlands for haymaking and pasture farming, the river for fishing and the woodlands as a source of timber [85]; however, details concerning land management remain vague due to scarce ethnographic studies in the Biebrza Valley. The serf system was abolished progressively in the nineteenth century [86]. After the abolition of feudalism, the local community managed wetlands under various proprietary conditions, depending on the village and political system.

Since the times of the first settlement, Poles, Rusini (Orthodox Eastern Slavic dialect speakers) and Lithuanians inhabited this area [84, 85]. Over centuries, the Biebrza River in the LBB was a frontier between changeably governed countries (like e.g. the Polish Crown and Lithuania in 1385-1568 or the Congress of Poland and the Russian Empire in 1815-1917) or Polish Provinces (like Masovia and Podlasie in 1569-1795) [87]. Even though the whole Biebrza Valley has belonged to the Republic of Poland since 1918 and exclusively Catholic Poles live on both sides of the river in the LBB [88], remnants of the historical borders are still present in the self-perception of the local community. All informants living on the right side of the Biebrza River state: behind the river, there are Ruscy/Rusini, here, we are Mazury (related to ethnic group of Poles-Masurians, the former name of Masovians). Informants also often called people living on the left side of the river Podlachy (related to the province Podlasie) or Litwasy (related to times of Lithuanian influence). All informants from the left side of Biebrza confirm such naming. The same type of self-perception was one of the findings of Kiryło [78].

Owing to the fact that Biebrza wetlands functioned as a natural border, drainage was forbidden over the centuries. Large networks of channels (such as the Augustowski Canal) were built up in the second half of nineteenth century [87]. However, the floodplain of the LBB with its natural hydrological conditions remains well preserved to this day [89] and became the ultimate research area of this study. The wetlands of the LBB were collectively used not only by the local community but also by people living in distant villages (20-30 km away). However, people from distant villages have been progressively abandoning undrained wetlands of the LBB since the 1960s (Fig. 1). This was firstly due to the common 




Fig. 1 A timeline showing the key changes in the management and vegetation of wetlands and the main drivers behind these changes (Lower Biebrza Basin, Poland)

drainage of land for agricultural purposes in the outskirts of the Biebrza Valley (between ca. 1960-1980), which resulted in the retreat of farmers from the undrained wetlands [90]. Later, along with process of farming mechanisation starting at the end of the 1960s, the use of the scythe was gradually discontinued [73]. The undrained wetlands suitable for scythe mowing were inaccessible for tractors [91]. Even though local inhabitants continued to use wetlands to some extent, a massive process of overgrowing with reed and willows has started in the LBB [71] and traditional practices have gradually ceased. Currently, the economy in the Biebrza Valley and the whole Podlaskie Province relies on agriculture and tourism; however, it is an economically marginalised region compared to other parts of Poland [92], and it is marked by mass emigration [93].

The vegetation in the LBB (an area with a length of $30 \mathrm{~km}$ and a width of $12-15 \mathrm{~km}$ [91]) has a zonal pattern that is formed parallel to the course of the river. The five vegetation zones are distinguished according to plant composition, source of water and duration of floods. Reedbeds and marshes have developed in the first zone, which is adjacent to the river and periodically intensively flooded. They are dominated by OenanthoRorippetum, Glycerietum maximae and Caricetum gracilis associations. The second zone consists of tall sedges, which form tussocks dominated by such communities as Caricetum elatae, Caricetum rostratae and Caricetum appropinquatae. The first and second zones are ca. $2 \mathrm{~km}$-wide together. In the third zone, which is constantly supplied by groundwater, we find sedge-moss communities with species like Carex appropinquata, C. nigra, C. panicea (for vascular plant species author names see Table 5) and Acrocladium cuspidatum (Hedw.) Lindb. moss species. The fourth zone is never flooded, but it is watered by groundwater. Low-sedge-brown moss communities grow in this zone, with species like Carex diandra, C. lasiocarpa, C. flava and Drepanocladus revolvens (Sw.) Warnst., Hamatocaulis vernicosus (Mitt.) Hedenäs mosses, etc. The sedge-moss zones are altogether around $12 \mathrm{~km}$-wide. The final, narrow fifth zone on the valley edge consists of woodland dominated by birch and alder carr forest [74, 94-96].

\section{Pilot study}

To define the research area, we started pilot research in summer 2017, during which villages located along the whole Biebrza River were visited. This included some randomly selected settlements and those recommended by people interviewed along the way. Eighteen villages were visited during the pilot study (Gugny, Zubole, Zucielec, Bajki Stare, Stójka, Olszowa Droga, Kołodzieje, Giełczyn, Brzostowo, Mocarze, Klimaszewnica, Goniądz, Dawidowizna, Budne, Dolistowo Stare, Wolne, Nowy Lipsk, Lipsk) and an average of three members of the local community were interviewed per village. Open, unstructured interviews were applied [97]. Middle aged or elderly people seated on benches in front of their houses were approached or traditional-looking houses were visited. If these two methods failed, the head of the village was visited. After a short introduction of the researcher, a general explanation of the research and usually some small talk, people were asked a few introductory questions, such as: Do you live in this village? For how long have you been living here? Do/did you own meadows in the wetlands? Do you remember times when these meadows were mown with a scythe? Do you or your children still use the meadows? Do you know any other person in your village 


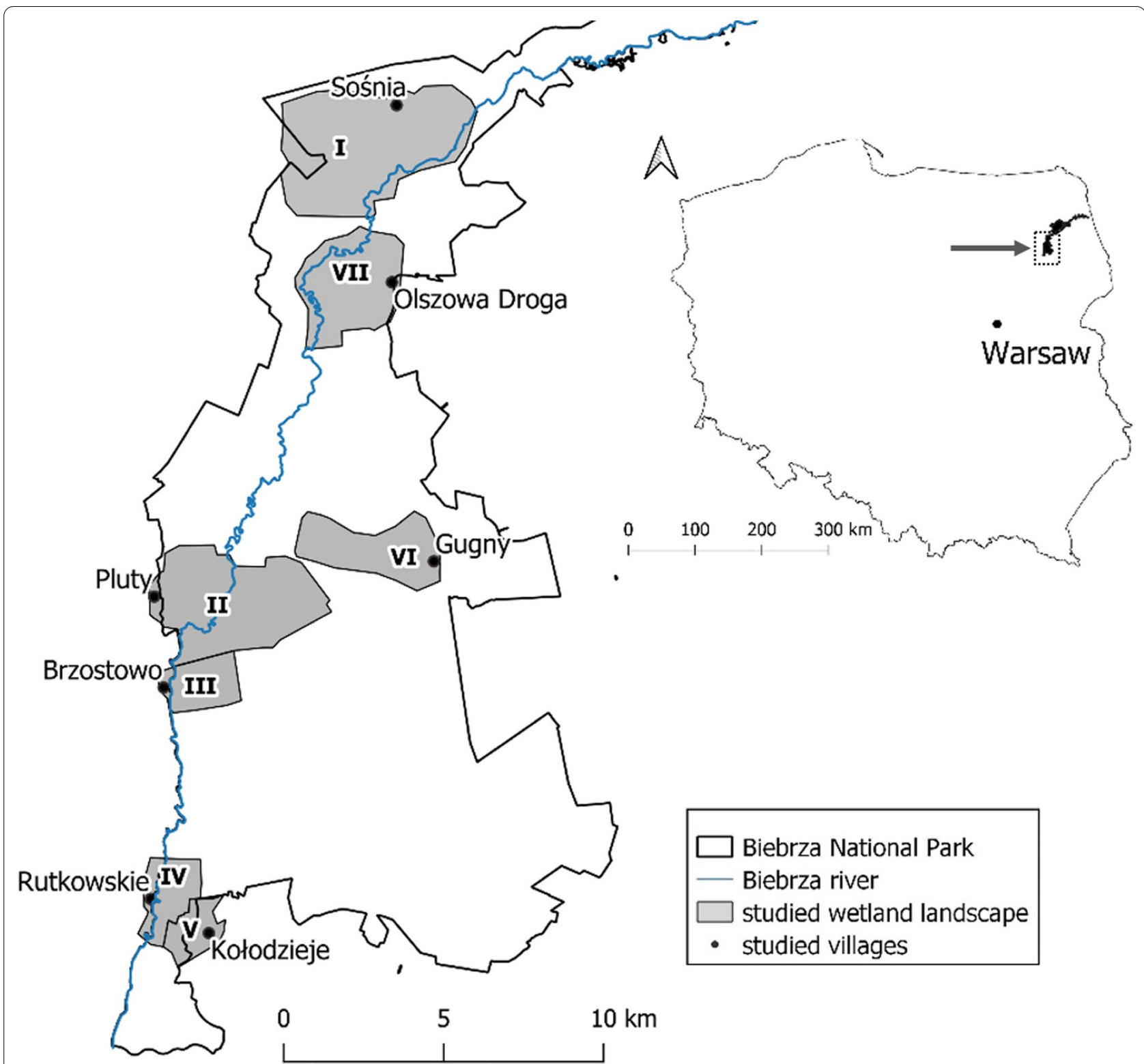

Fig. 2 The research area of the seven studied villages in the Lower Biebrza Basin of the Biebrza National Park (Poland)

who could help answer these questions? The first conversations with new persons were not recorded, which facilitated spontaneous and open conversations. Notes were taken during every conversation. The pilot research aimed to identify the key villages for further researchthose inhabited by a sufficient number of knowledgeable informants as well as people with less extensive knowledge willing to participate in the research.

\section{Final study sites}

During the actual study, continued in the years 20182020, seven villages in LBB (Fig. 2) were selected and intensively studied using the same methods. The villages will henceforth be symbolised by Roman numerals. The villages were usually visited during summer, as the full vegetation season allowed for the application of most of the field methods. It was also noticed that people were more open and talkative in the summertime than in late autumn and winter. Each of the studied villages was inhabited by at least two local people with extensive wetland ecological knowledge. The villages are located on different sides of the Biebrza River. Four of them stand on the right side of the river, and inhabitants of these villages own meadows in the wetlands directly connected to 
Table 1 Demography of the studied villages and the interviewed local people

\begin{tabular}{|c|c|c|c|c|c|}
\hline Village & $\begin{array}{l}\text { No. of inhabitants } \\
\text { (2011) }\end{array}$ & $\begin{array}{l}\text { No. of informants (No. } \\
\text { acc. to gender) }\end{array}$ & $\begin{array}{l}\text { Age range of } \\
\text { informants (in 2018) }\end{array}$ & $\begin{array}{l}\text { No. of interviewed } \\
\text { active farmers }\end{array}$ & $\begin{array}{l}\text { No. of } \\
\text { interviewed } \\
\text { retired farmers }\end{array}$ \\
\hline Sośnia & 12 & $2\left(09+20^{*}\right)$ & $65-70$ & 0 & 2 \\
\hline Pluty & 136 & $7(0$ + 7ð゙) & $40-89$ & 4 & 3 \\
\hline Brzostowo & 104 & $8\left(2 q+60^{*}\right)$ & $29-85$ & 2 & 6 \\
\hline Rutkowskie & 150 & $3\left(1 q+20^{*}\right)$ & $57-84$ & 0 & 3 \\
\hline Kołodzieje & ca. 30 & $5\left(3 q+2 \delta^{\star}\right)$ & $58-81$ & 1 & 4 \\
\hline Gugny & 5 & $7^{\mathrm{a}}\left(19+60^{\star}\right)$ & $58-84$ & 1 & 6 \\
\hline Olszowa Droga & 30 & $10\left(0 q+10 o^{\wedge}\right)$ & $30-88$ & 4 & 6 \\
\hline In total & & $42\left(7 \%+35 o^{\star}\right)$ & & 12 & 30 \\
\hline
\end{tabular}

${ }^{a}$ The number of informants in the village of Gugny is higher than the number of inhabitants due to interviewing people who used to live in the village but had already moved out

the river. The remaining three villages stand on the left river side. One village has meadows connected to the river, and in the other two, the meadows are not adjacent to the river. The exact wetland area of study was limited to the landscape recognised by and familiar to inhabitants of the village; the area local people would tell stories about and describe with the use of toponyms; the area owned by the inhabitants of the village in times of traditional management (even if it is not owned by them right now). The studied landscape ranged from 2.5 to $18.6 \mathrm{~km}^{2}$ in size. People could usually recognise a wider area, which used to be explored only in wintertime. In summertime, most of the paths connecting the two sides of the wetlands were not accessible because of high water level. Only the frozen water surface made it accessible to the villages on the other side of the river, and people from different sides of the river could meet during, e.g. winter dance parties. However, the wider landscape is perceived in a more general way, and people struggled localising some of the toponyms. Therefore, it is not included in the study.

The villages also vary according to their demography and economy (Table 1). Three villages-Pluty, Brzostowo, and Rutkowskie-are the largest studied villages, with active young farmers. Two other villages (Kołodzieje, Olszowa Droga) are much smaller but also inhabited by young and active farmers. The two remaining villages, Gugny and Sośnia, are currently abandoned by farmers, but until the 1970s these villages were active and populated by several dozen families, as stated by informants.

\section{Data collection and analysis}

The interviews were carried out with people whose families lived in the same area (the same or the neighbouring village), at least two generations back (their grandparents' generation). Often the most knowledgeable informants had a surname similar to the name of the local village or to names from the local community mentioned by Gloger [77], which additionally affirms the local origin of the informants. Each informant was interviewed at least once. People with the greatest ethnoecological knowledge were interviewed 2-4 times, with the conversations lasting from two to three hours. The next informant in the village was usually found using the snowball method [97]. People asked to point the villager with the deepest knowledge would, as a rule, indicate the same personsprobably the most reputable individuals in the village. The conversations had the character of semi-structured interviews, launched with a few questions mentioned in the description of the 'pilot study', and continued with more precise questions (Table 2). For the purposes of interview dynamics, the type and the order of the questions were adjusted to the course taken by the informant, as moderated by interviewer.

After the first visit in the village and a few initial conversations, during the next interview, questions were sometimes stated in a modified way, by the usage of local expressions describing elements of landscape or vegetation. If the new expression was identified, during the next interview the same person and other people in the villages were asked again for the definition of the term to ensure its meaning. All interviews were literally transcribed and $77 \%$ were digitally recorded. The collected traditional knowledge and narratives used by people (besides plant knowledge and toponyms, which were analysed separately) were grouped in a database according to topic (e.g. grazing livestock, time of grazing, mowing technique, time of mowing, haystack structure, wetland value).

To detect if people had knowledge about the plants, the questions related to plants from Table 2 (point 5), were asked. In the next step, to correctly identify ethnospecies to botanical species, one or two of the following methods were applied [97] in the case of the most 
Table 2 The sort of the questions used in the semi-structured interviews exploring people's TEK

1. To get a general overview of life in the village and understand the informant's perception of farm life and the changes in local agriculture: Has life in the village changed in the last few decades? What were the main reasons for such changes? Have farming practices in the villages changed? How do you evaluate these changes? What changes influenced farming practices the most?

2. To understand the relation of people to the wetlands and their value for people:

Was it profitable to have meadows in the wetlands? Did their value change? When did you last go to the wetlands? Have you ever mown with a scythe? How much time did you used to spend in meadows in the past? What would you do there?

3. To learn about traditional farming practices in wetlands:

On what terms did people manage wetlands historically? How did the time of haymaking look in this village? How did people use wetlands, meadows and forests? What did mowing practices look like in the times of hand mowing? How did you build a haystack? When and where did people mow? Why in this particular time and place? When did people stop using the scythe in this village? For what reason? Did you continue to use your meadow after the discontinuation of hand mowing? How has the practice of mowing changed?

4. To learn about grazing practices in the wetland:

Did you have livestock? What animals did you have? Did animals graze in wetlands? Where and when did certain livestock graze? When did the grazing season start and finish? Why? Did animals graze in the wetland forests?

5. To learn what people know about plants and account for observed changes in vegetation:

Which plants grow in wetlands? How do you recognise this plant? Where does this plant grow? Is it a common plant? Did the occurrence of this plant change? What do you think, why? Is this plant good for hay? Did animals graze this plant? Which other plant species were grazed?

6. To recognise the perception of the landscape and toponyms used by people:

Where do the most valuable/the worst plants grow? Where were certain farming practices performed (like mowing, grazing, peat excavation, and fishing)? Where is your own plot located in the wetlands? Where did the mowing start, where did it finish? Where were the haystacks built? Where did you find material for building haystacks?
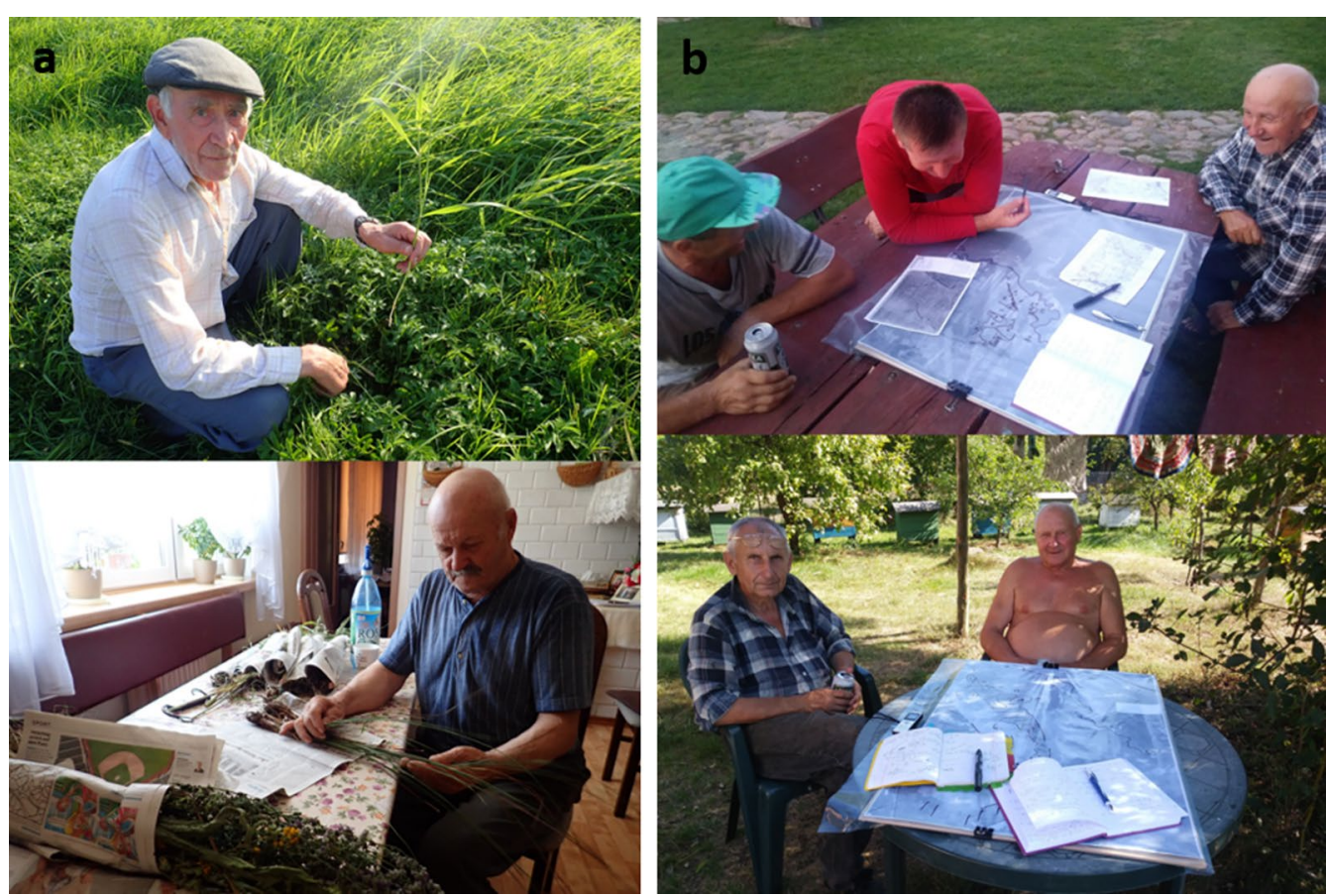

Fig. 3 Data collection in the Biebrza Valley (Poland). a Plant species identification: above-walking with the informant in the wetlands, belowusing fresh voucher specimens (Photos by J. Sucholas, 2020). b Mapping work-informants from different generations cooperate while creating the local wetland map (Photos by J. Sucholas, 2019)

knowledgeable informants (Fig. 3). First, just before the interview, fresh voucher specimens were collected in the wetlands belonging to the village; later these visual stimuli were presented to the informant. This method was applied the most often, and it was the most successful in terms of plant verification by informants. People often immediately recognised plants they could touch, smell, and see in their real size. Second, if the interview was 
held in the winter season, another kind of visual stimulus in the form of pictures of the wetland plant species was used. For this method, A4 size sheets with photographs of 125 vascular plants occurring in the LBB were shown to the informant. This method turned out to be the most ineffective, as it was challenging for informants to recall plants on the basis of their pictures. After a few applications, the method was no longer implemented. Finally, in every village, one guided tour in the wetlands with the most knowledgeable informant in the village was made to identify plants in the field and note for changes in vegetation observed by the informant. This method was effective in terms of informants identifying ethnospecies and sharing remarks about changes in vegetation. All the ethnospecies mentioned by informants at least twice and ecological knowledge about these taxa were set into spreadsheet. The ethnospecies were classified into lower and higher systematic domains after folk biological taxonomy and nomenclature proposed by Berlin [98] and Brown [99]. The scientific plant nomenclature and author abbreviations follow The Plant List. ${ }^{1}$

To understand the perception of the landscape by the local community, locate the land-use practices and learn the toponyms used in the village, people were asked questions from Table 2 (point 6) related to landscape perception. Often, the toponym interviews were group interviews with older and younger generations. The younger man (son or neighbour) assisted the older man to arrange toponyms on the map (Fig. 3). Sometimes, together with the informant, the wetland landscape and its partitioning were drawn by hand on a sheet of paper. Printed maps were used for precise localisation of certain management practices and toponyms in the landscape. For each wetland landscape of the seven studied villages, A0-size maps were printed at 1:25,000 scale. Three maps shared by the Biebrza NP were used: the topographic map from 1960 , aerial pictures from the area (from times of traditional management, July 1966-1967) and the most recent orthophoto map (July 2015). For mapping toponyms, the informants could use the map they found most familiar and understandable. All information related to the map was plotted on transparent overlays. If the area was covered with too many names, number coding was used for toponyms. The landscape partitioning presented in the results, the simplified traditional land-use map (showing practices from the 1960s) and a cross section of the elevation pattern were created with Inkscape Software. We set toponyms and the information noted during interviews (e.g. explanation of the toponym's meaning, traditional

\footnotetext{
${ }^{1}$ The Plant List (2013). Version 1.1. Published on the Internet; http://www. theplantlist.org/ (accessed 12 February 2021).
}

practices that took place in this location or related oral stories) in the spreadsheet. Afterwards, we clustered toponyms into the landscape element sets named by these toponyms.

\section{Results \\ Who knows what?}

The research revealed the presence of LTEK possessed by members of the local community in the Biebrza Valley, varying in type and complexity according to age, gender and personal qualities (like good memory or talkativeness). Women constituted $15 \%$ of all informants. Only elderly women were recommended as 'good informants' in the village. All of the women informants were above 70 years old. Their descriptions of traditional practices were very simplified and general; they were able to list a few wetland species (mean of $7 \pm \mathrm{SD}=2.5$, max. of 11). As a rule, they had a good knowledge about medicinal plants species, because they used to collect them for trade besides dealing with farming duties. The majority of the informants were men who had usually farmed their whole life. Among them were two local foresters and two beekeepers who also worked on farms of their own for at least part of their lives. We distinguish three groups of male informants according to age: 1st-older than 70 years (15 persons), 2nd-between 46 and 70 (14 persons) and 3rd-between 29 and 45 years (six persons). The informants from the oldest group had experienced wetland mowing by hand as adults. They were the major source of information about studied traditional practices, the annual cycle of hay management, agricultural transitions and the drivers behind them, and long-term changes in the landscape and vegetation (as eyewitnesses to all of these processes). In this group, two men were the most insightful informants from all the interviewed people. The younger men from the 2nd group experienced times of mowing by hand in childhood, remembered traditional farm life more from observation and oral stories transmitted by the elderly than participation. Nevertheless, all of these informants had used a scythe at some point in their lives. Frequently they were not sure about the chronological order of the historical changes in farming or the details connected to certain wetland use practices. Men from the 3rd group did not experience mowing with a scythe at all and could not remember any traditional practices. Nevertheless, all of these young farmers were taught farming by their fathers to some extent and continued to use meadows in wetlands.

Informants from the 1st group could name a mean of $14 \pm \mathrm{SD}=9.3$ plant species (max. of 36 ); the 2nd group could name a mean of $16 \pm \mathrm{SD}=9.2$ species (max. of 40 ); the 3rd group, a mean of $8 \pm \mathrm{SD}=3.3$ species (max. 13). However, the group of the oldest informants provided the 

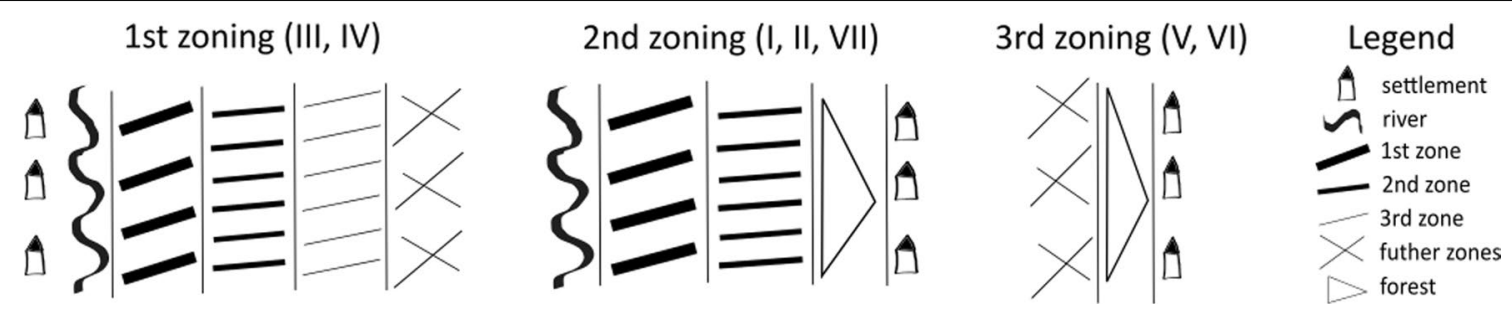

Fig. 4 The three types of partitioning (zoning) of wetland landscape in the studied villages (Biebrza Valley, Poland) differentiated by local people. The Roman numerals in parentheses indicate the village: I—Sośnia, II—Pluty, III—Brzostowo, IV—Rutkowskie, V—Kołodzieje, VI—Gugny, VII— Olszowa Droga

most comprehensive, almost 'palpable' descriptions of the plants' features, habitats and farming value, in contrast to the younger informants who, even if they listed more species, could rarely name more than two qualities of the plant. The group of youngest informants could list species, though they struggled to identify them properly.

The knowledge of toponyms was shared usually during group interviews by $2-3$ persons per village. The informants were from all age groups and cooperated while mapping work. The representatives of the youngest generation were full-time farmers. Informants from the 1st and 2nd group provided all toponyms used in the village. Farmers from the youngest generation who facilitated the mapping work were usually familiar with the majority of the toponyms, but some were new to them. Informants as a rule named toponyms while describing the location of their plot or farming activity in the wetlands.

\section{Formerly, Biebrza meadows were the only livelihood (III)}

People repeated that wetland meadows used to be of great farming value: these meadows were a treasure (...) generally it was good hay and the cow could eat everything (VII). Informant also added that the wetland meadows were the only type of meadows available to local people in some villages: Who would suppose that one could have a meadow in a crop field (not in the wetland)? No one knew that! (III). It was the reason behind the high economic value of wetland meadows, expressed by many other narratives: formerly, a man had to pay big money to buy a meadow (...) a man would sell a crop field to buy a wetland meadow (III); at that time, 1 ha of a meadow had a value of 350 pigs (...) people had to collectively buy meadows (VII); the one who had meadows along the Biebrza was rich (VII). People connected the moment of the rapid drop in the value of wetland meadows with the moment of discontinuation of scythe use: when the scythe 'collapsed' then the value of the meadow dropped prospectively (...) we abandoned these meadows (III). Informants also confirmed that drainage of some of the land was the main reason for the abandonment of undrained wetlands: after melioration we didn't use them much anymore. It drove us out of the Biebrza meadows; we stopped using them en masse (VII). Additionally, people indicated the role of artificial fertilisers, which greatly improved the productivity of drained meadows. Indeed, in this region, in the late 1970s, the Association of Agricultural Cooperatives' (Spótdzielnia Kótek Rolniczych, SKR) started operating actively and influenced farming practices by e.g. convincing farmers to use mineral fertilisers: they asked us to buy it so we used a lot of it (V). This dramatically diminished the value of undrained wetland meadows, which were impossible to fertilise and less productive: there is no sense in using fertilisers on the Biebrza meadows, because water will wash out everything (II). Until the process of agricultural intensification in the Biebrza Valley, haymaking and grazing predominantly took place in wetlands.

\section{Three types of wetland landscape partitioning}

People perceive the Biebrza River as the main natural border dividing the landscape and vegetation into two major areas: before the river and on the other side of the river (the latter was generally called zarzecze). We identified three general types of wetland landscape partitioning present in the narratives and perception of the inhabitants of studied villages (Fig. 4). This perceptual division of wetlands into management units depends on the location of the village and roots in traditional practices; it is directly associated with the vegetation type, quality of hay, and division of land ownership.

For villages situated directly in front of the river (1st zoning) the whole managed wetlands lie on the other side of the river. Inhabitants of these villages use the term branie, 'taking', for the zones they distinguish in the wetlands. This expression is connected with a mowing practice-'taking hay'. The first zone is called pierwsze branie 'first taking'; the next zone is called drugie branie 'second taking. This pattern continue in the further zones. In the case of these villages, rzeczna trawa, 'river grass', which produces the best quality hay, occur 
in the first two zones. The 'river grass' was either mown twice a year and used as pasture in autumn (IV) or the 'first taking' was used for the whole season only as pasture, smugi, and the 'second taking' was mown once a year and mixed with grazing (III). In the 1st wetland zoning, all of the following zones, which have worse-quality hay, are called biele or bielne taki-'white meadows' (III, IV): every next taking provides a lower hay quality (III). These meadows were mown only once a year (IV) sometimes mixed with less intensive grazing (III, IV). They are also called pracowite taki 'hard working meadows' (IV), because they are arduous to mow due to the presence of sedge tussocks. The term 'white meadows' is alternatively used in a wider context to name all the wetland meadows and distinguish them from any other meadows outside of the valley. The name derives from the phenomenon of fog overlaying the meadows in the mornings and evenings, which, from the perspective of the village, gives an impression of 'white meadows'. However, in further descriptions regarding the 'white meadows', we mean, as abovementioned, wet meadows of worse hay quality.

For the inhabitants of villages situated further from the river (2nd zoning) the wetland landscape on the two sides of the river has two major zones. The first zone of trawa rzeczna, 'river grass', directly by the river, produces best hay quality and was mown twice a year (I) and mixed with grazing (II, VII) or mown once and mixed with grazing (II). The second zone is called 'white meadows' and was mown once a year for hay mixed with grazing (I, II, VII). In this case, the forest separates settlements from meadows.

The informants from the village who own wetland without connection to the river (3rd zoning) call all wetlands belonging to them taki torfowe 'peat meadows' (VI) or use the general term for worse meadows 'white meadows' (V, VI), as discussed before. These meadows, situated the farthest from the river, produce the worst hay quality and had different use (see Table 3 ).

\section{Landscape of traditional practices}

The landscapes of the studied villages consist of repeating elements, structures or habitats, however, seen from different 'village' perspectives, their traditional function and use varied (Table 3). Figure 5 presents a simplified map illustrating the traditional landscape of the village Pluty (II), which is the most diversified among the studied villages.

The situation of this village in relation to the river is exceptional, as there is a large accessible area of usable wetlands before the river. The village stands out with the highest number of toponyms saved in the memory of the people (mainly the older informants) -87 in total (on $14.1 \mathrm{~km}^{2}$ ). Less than $18 \%$ of all toponyms refered to the area of use on the other side of the river, zarzecze. The vast majority of the toponyms name elements of a landscape of an area less than $5 \mathrm{~km}^{2}$ in size, in front of the river. A similarly high number of 69 toponyms is used in the village Sośnia $\left(18.6 \mathrm{~km}^{2}\right)$, now abandoned by its native inhabitants. The village is also situated on the right side of the river and separated from the river by an extensive area of accessible wetlands. Both wetland landscapes (I, II) have been the most anthropogenically modified by piled up roads, digging ditches and peat excavations in former times. Fifty-five toponyms were collected in Rutkowskie and Kołodzieje, the wetland landscapes of which overlap $\left(6.1 \mathrm{~km}^{2}\right)$; then 46 in Olszowa Droga $(9.2$ $\left.\mathrm{km}^{2}\right)$; 30 in Gugny $\left(5.5 \mathrm{~km}^{2}\right)$; and 27 in Brzostowo (3.6 $\mathrm{km}^{2}$ ). We can see that the more diversified the landscape is by the presence of many oxbow lakes, ditches, paths, mineral islands and the like, the more toponyms were invented by inhabitants. However, people underlined that: in the past more names were in use that are forgotten now (II). The local wetland map, rich in many toponyms, was necessary for the local community to orientate itself on the, even if modified, still broad, monotonous and flat landscape. It helped to find his or her own plot, which was not separated by any fence. Sometimes borders were marked with stones (II), small poles (III) or willow branches (IV, V). ${ }^{2}$ However, such a map exists only in the memory of people who never preserved their oral transmission in written form. The toponyms of meadows were derived from the surname of the owner, the name of the owner's village, a neighbouring landscape element such as e.g. an oxbow, a distinctive landscape feature or certain farming practices. The information about times of traditional farming is encoded in toponyms. For example, toponyms indicate places of former peat excavation, owners of meadows (even if 40 or more years have passed since the land was under their management), grazing animals, growing plant species etc. Generally, even the oldest farmers admitted that they do not know the origin of a name and said that it is very old.

As a rule, the landscape element closest to settlements is ogród, the 'garden', where people used to grow vegetables and cultivate plants for fibre, such as flax or hemp. Pola, 'fields'-the ground on the elevated banks of the valley-were used as arable land to grow potatoes and cereals like oats, rye or millet and located around houses (I, V, VI, VII) or behind them (II, III, IV). The old

\footnotetext{
${ }^{2}$ Plots in the Biebrza Valley are long and narrow due to the still present legacy of traditional land fragmentation along the length of plots, so that the plot became narrower and narrower but remained constant in length. In former times the long and narrow plots perpendicular to the river were assigned equally to people, so that everyone got better quality meadows by the river and the worse ones further from the river.
} 


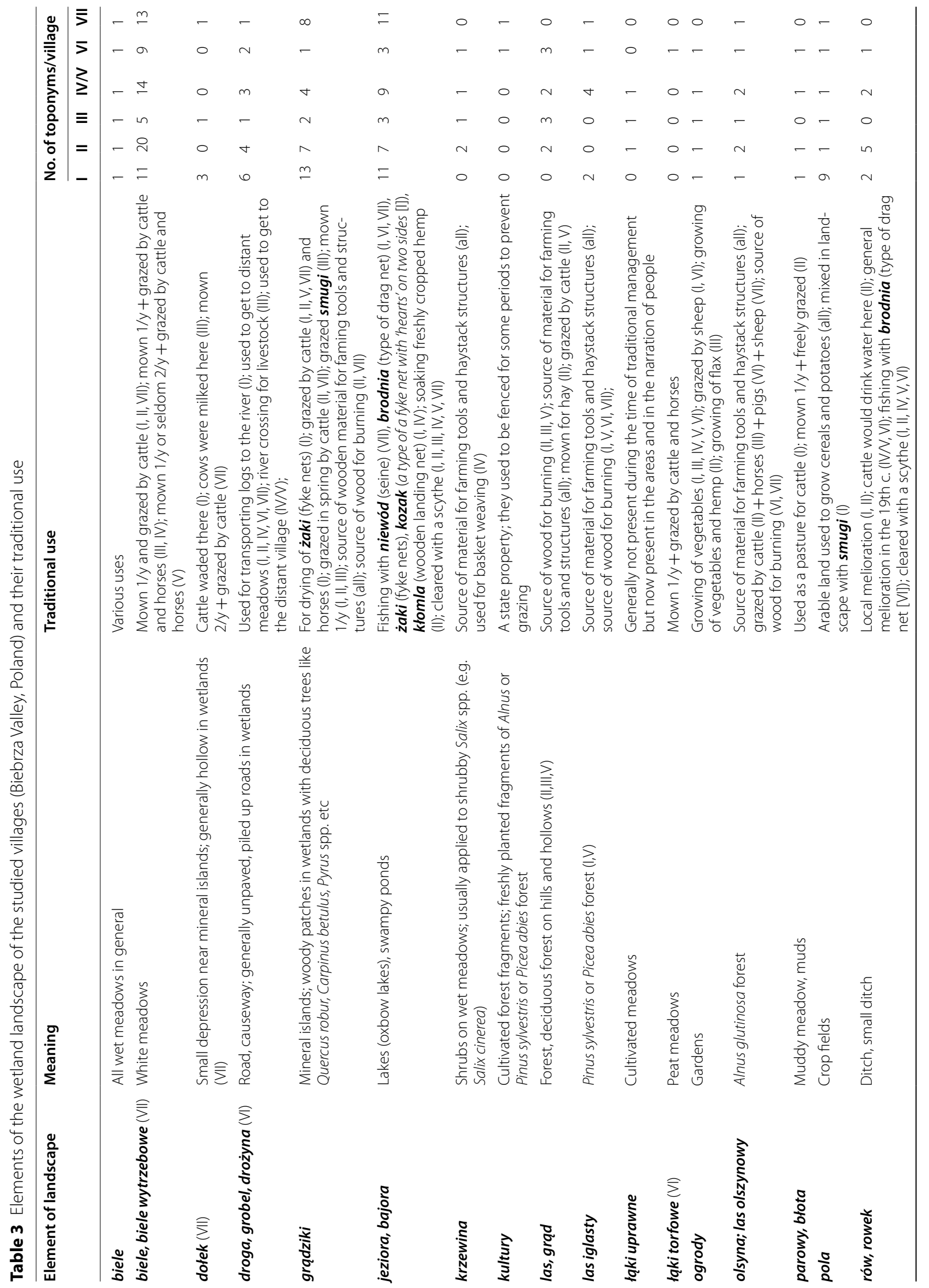




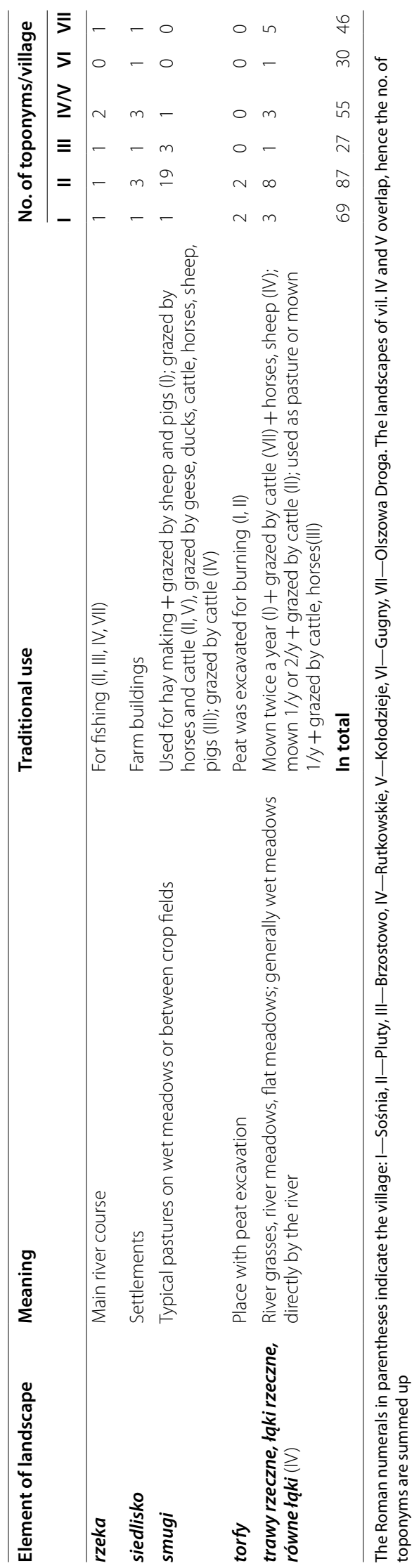



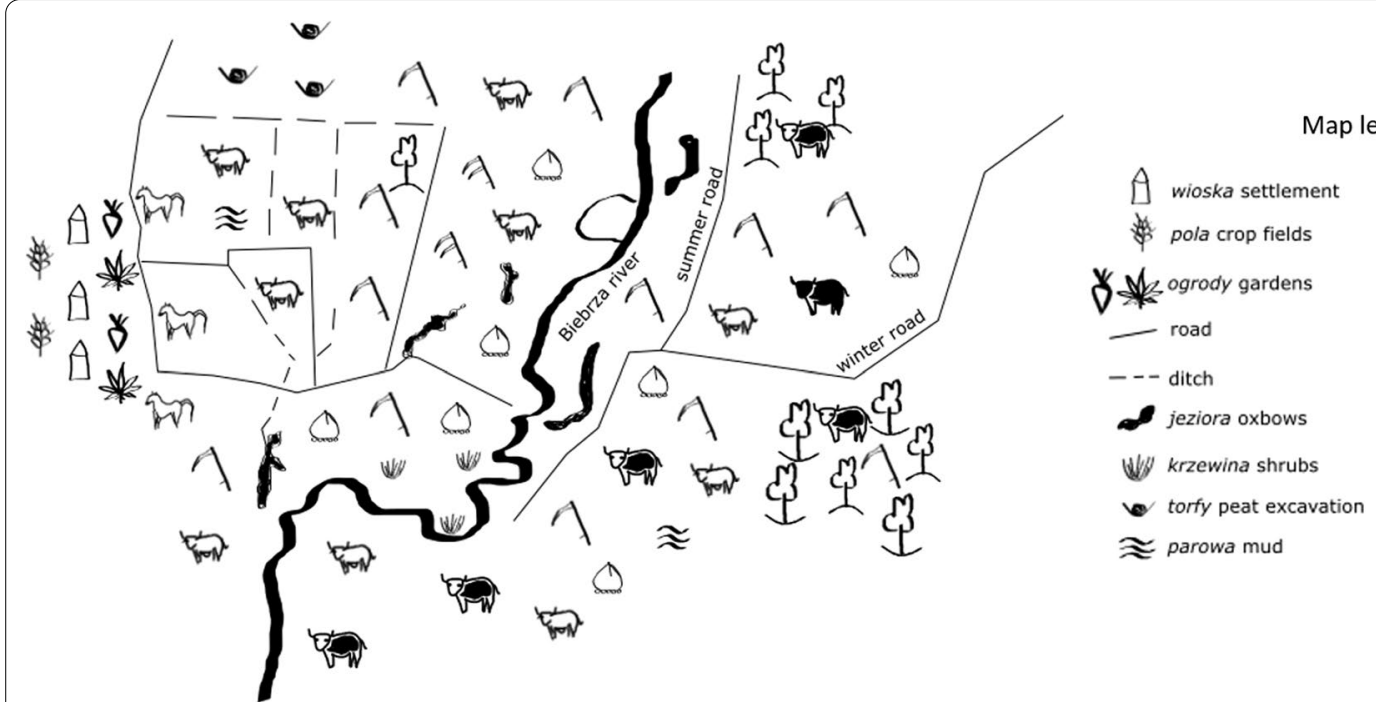

Map legend

Fig. 5 A simplified map presenting the traditional land-use of one of the villages, Pluty (II), in the Biebrza Valley, Poland, in the 1960s. Drawn by J. Sucholas. For detailed explanation of landscape elements see Table 3

riverbeds-oxbows-are a frequent element of the landscape of villages with access to the river. Notably, the landscape of wetlands near the villages from the upper LBB is dominated by oxbows marking old courses of the Biebrza River (I, VII). In times of traditional management, biomass in the oxbows and in the ditches was regularly removed with a scythe. Stories about using oxbows for fishing with traditional equipment are still vivid in the memory of the people. The term taki uprawne 'cultivated meadows' is now applied to the meadows outside the valley as distinguished from biele (all wetland meadows in general). Fertilisers and seed sowing improve the productivity of cultivated meadows.

Mineral islands occur as elevated deciduous woody patches in wetlands and served many functions for people (Table 3). Grazing livestock could find shelter, shadow and fodder there. Mineral islands were the first accessible pastures in the wetlands in springtime (III, VII). The islands served as the safest place to build haystacks, secure from high water levels. The natural depression, dotek, adjacent to the mineral island produced the thickest and best hay quality, dedicated especially to sheep: hay from the hollows was deliberately separated in a haystack for sheep that ate it directly 'in the air' (very quickly, before hay reached the ground in the barn), it was of such a wonderful aroma (VII).

Predominantly, the term smugi refers to the area that is used solely as a pasture. In one village (I), smugi relates to the small meadow stripes formed in the wet depressions between stripes of elevated crop fields, not only grazed but also mown. ${ }^{3}$ This characteristic stripe mosaic of meadows and crop fields was situated only near the settlement (I). Pastures, smugi, were either found in wetlands (II, III, V), or around settlements (all villages), or exceptionally in the area of the crop fields (I, IV). The majority of the smugi in wetlands as well as some forests were used by the whole village. Such areas were named ogólne-'communal' (common land).

The inhabitants noticed even slight vertical drop between the river's course and the surrounding floodplain (Fig. 6). They understand that water flooded from the river and its content work like fertilisers, thus the 'river grasses', which were flooded most intensively, have the utmost hay quality and are the most productive, in contrast to the most distant 'peat meadows' that are not flooded by the river and are the most unproductive. Additionally, people differentiated plant habitats by a vertical drop-some of the plants grow in higher, others in lower wetlands e.g. in relation to the elevation to the river. The direction of the flooding water and its practical meaning in wintertime were also observed: when the first frost came, the haystacks built on lower wetlands had to be transported to stables in the first place, otherwise there was a danger of the stacks being undermined and destroyed by the water coming quickly up-down the ice (VII).

\footnotetext{
${ }^{3}$ Information obtained from the last two elderly inhabitants of the village they might have an incorrect memory of how smugi were used.
} 


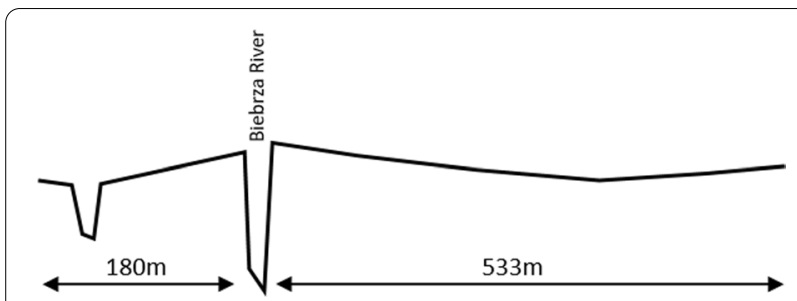

Fig. 6 Fragment of a cross section of the elevation pattern in wetlands by the Biebrza River (based on stratigraphic cross section no. 22, Olszowa Droga village area, made in 1960s, from Wyniki badań glebowo-florystycznych w dolinie Biebrzy dolnej by J. Oświt, 1965 [100])

\section{Local traditional wetland management practices}

The annual cycle of hay management practices in the wetlands was conditioned by natural factors, of which water level was the most important: Everything depended on water (all villages) (see Fig. 7). Open areas and forest in wetlands were the major habitats used to feed the livestock, especially cattle and horses, but also pigs, sheep, geese and ducks. In the early spring, when water moved back from the wetlands and the first grass was visible, cattle was released for grazing on mineral islands (II) or since the beginning of May milk cows grazed there (on mineral islands) the whole month, day and night (...) twice a day we went there by boats for milking (VII) (Table 4). Since the pastures in the open wetlands had no fences, livestock either grazed freely in large areas or all cattle belonging to a village was herded by one person, sometimes even a child, in turn: kolejka; wypas kolejka, 'queue'. According to this method, the owners of the cattle tended them one by one, for a number of days equal to the number of owned cattle or half of this number (all villages). The fowl (geese, ducks) was usually kept in small pastures around the settlements, besides one village with easy access to mineral islands on the other side of the river (III). This area was used as pasture, smugi, for various livestock species grazing altogether (Table 4). The situation was similar when it came to pigs, which foraged near the houses, with the exception of the abovementioned village, where they were fed in 'river grasses' (III) and villages (VI, VII) where pigs would graze freely in the Alnus forest nearby the settlements. A few informants said that cattle used to eat saplings in spring (VI, VII), which occasionally had ill effects: everyone had to have vinegar at home to cure a cow which used to have blood in urine after eating saplings of the lime tree (VI). Sheep were fond of grazing wetland meadows, however, they required drier ground and had to be in sight of people to protect them from wolves. Because of this, they grazed close to the settlements: in drier smugi (I), 'river grasses' (III, IV) or Alnus forest and biele in autumn time (VII). Interestingly, in the past, one of the villages (IV) already had pastures in the zone of crop fields, which were grazed by cattle, horses and sheep until the last mowing date in the wetlands. After the second mowing in the wetlands, the livestock could freely graze 'river grasses' belonging to this village. Horses ordinarily grazed freely in the wetland meadows and forests at night, since during the day they were needed at the farm: horses made groups while walking in wetlands in the night to protect themselves from the wolves (VI). Sometimes catching the scattered horses in the morning was challenging, so the horses were herded to the heaviest mud to hogtie them (VI). In one of the villages (II) they grazed in wetland pastures situated very close to settlements during the day. The following four types of cattle grazing regimes in wetlands are noted: (1) if the wetlands were intended for hay making and had to produce grass, the cattle grazed in forests during this period, usually tended by the owners in turn using the already described kolejka system (V, VI, VII); (2) they grazed pastures close to settlements until the last mowing in wetlands (IV); (3) in the case of large wetland areas, heifers were herded to the biele in early spring and grazed freely day and night until autumn (I, II, III); (4) the lactating cows could graze biele destined for mowing under the herder's supervision (I, II, III). The lactating cows were either visited twice a day and milked in wetlands or milked every evening once back home. Many informants believe that cows had less milk in their udders after grazing wetlands, because it was 'sucked out' by the snakes. Traditionally, livestock grazed in wetlands until first snow-do zapadtych-as confirmed by all informants.

All informants admitted that the time of the first mowing depended on the water level: grass started to grow at the end of May (...) usually, first mowing was at the end of June (...) but it depended on the water level (VII) (Table 4). However, as a rule, the Catholic feast days, e.g. St. Peter's Day 29th of June and the Nativity of the Blessed Virgin Mary 8th of September, fixed the start of the first and second mowing respectively, which would begin one day after them. However, if the water level was still high, the first mowing could be delayed until July. At the time of traditional management, all open wetlands and grass in deciduous woody patches were mown: formerly, with a scythe, everything was mown as low as possible (...) with a scythe one could enter everyplace, even if the water was still there (VII). The time and place of the second mowing was conditioned by the water level and type of vegetation. Nevertheless, grass needed to be cut at the beginning of September at the latest: if hay was cut later, cattle did not want to eat such hay (VII). Sporadically, intensive rainfall in summer prevented the second mowing. All 


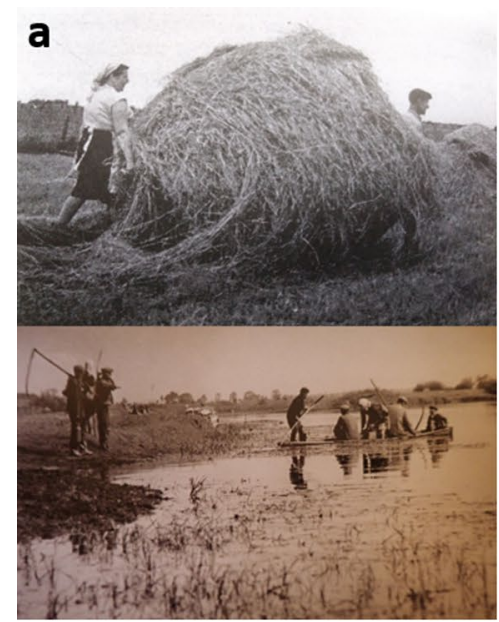

d
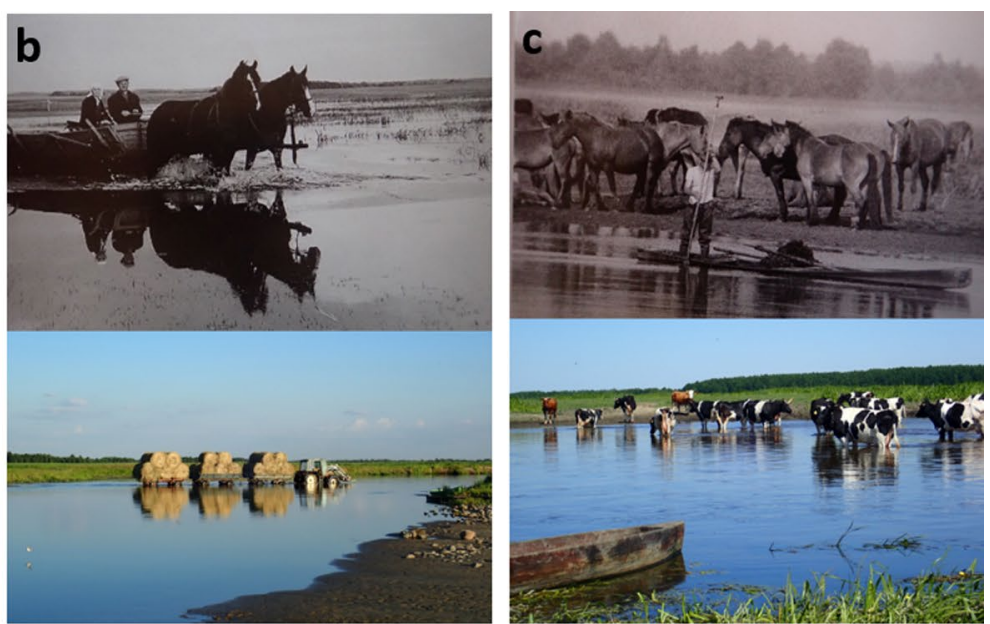

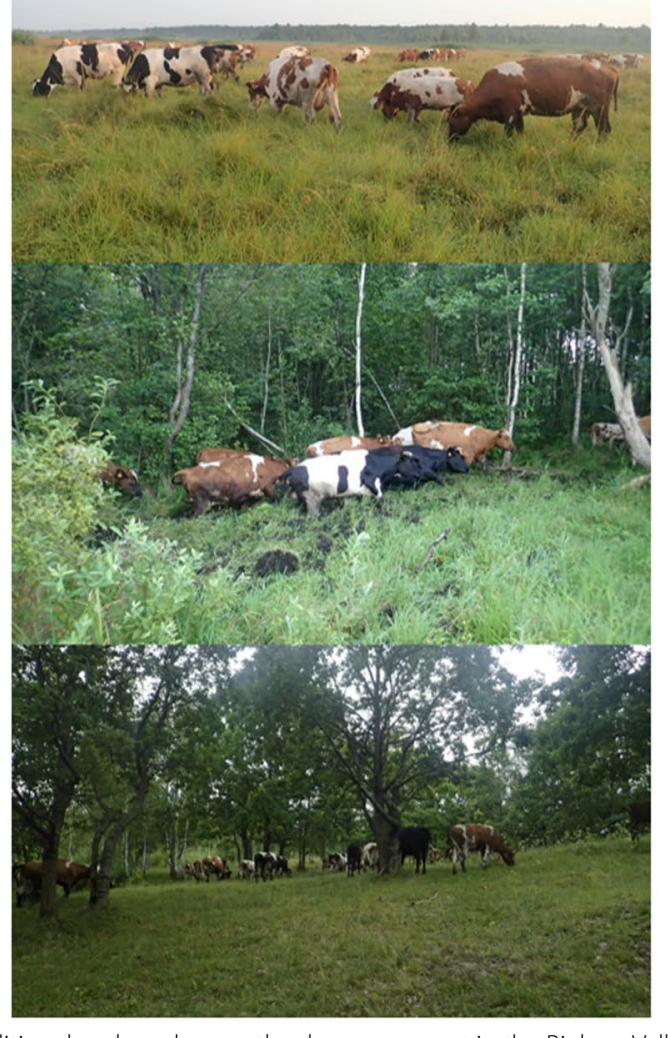

Fig. 7 Traditional and modern wetland management in the Biebrza Valley (Poland). a Traditional hand hay management: above —carrying small. haystack on wooden spruce rods (Photo by M. Pokropek, 1968), below — preparing to mow with a scythe (Photo by J. Rybiński, 1960s). b Transport across the river: above - with horses (Photo by J. Rybiński, 1960s), below — haybales transported with a tractor (Photo by J. Sucholas, 2019). c Livestock grazing wetlands on the other side of the river: above — horses (Photo by W. Wołkow, 1960s), below_cattle (Photo by J. Sucholas, 2018), d cattle grazing three types of habitats: uppermost—open wetlands, middle_Alnus forest, below_Quercus forest on mineral islands (Photos by J. Sucholas, 2018), e hay storing: above — traditional haystacks in the wetlands (Photo by J. Rybiński, 1960s), below—modern bales (Photo by J. Sucholas, 2019), f traditional haystacks on Biebrza wetlands: above—haystacks, below: empty haystack platform (redrawn after Denis Clavreul from Portrait of a Living Marsh by Robin D'Arcy Shillcock, 1993 [101])
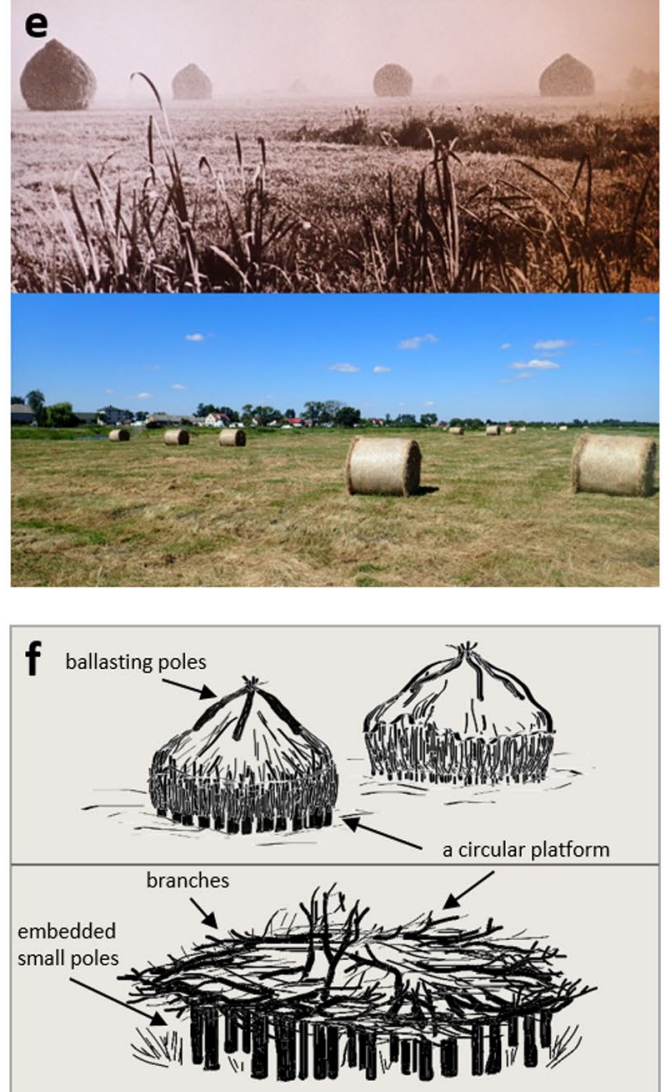
Table 4 Time and place of traditional farming practices such as mowing and grazing in the Biebrza Valley

\begin{tabular}{|c|c|c|c|}
\hline \multicolumn{2}{|c|}{ Traditional practice } & \multirow{2}{*}{$\begin{array}{l}\text { When } \\
\text { Around St. Peter's Day 29th of June (II, III, V, VI, VIII), around St. } \\
\text { John's Day 24th of June (I, IV) }\end{array}$} & \multirow{2}{*}{$\begin{array}{l}\text { Where } \\
\text { biele }(\mathrm{V}) \text { + river grasses }(\mathrm{I}, \mathrm{II}, \mathrm{III}, \mathrm{IV}, \mathrm{VII}) \text {; peat meadows }(\mathrm{VI}) \text {; } \\
\text { smugi }(\mathrm{I}) \text {; mineral islands (all); grąd (II); depressions (VII) }\end{array}$} \\
\hline Mowing & First & & \\
\hline & $\begin{array}{l}\text { Second; called } \\
\text { Otawa or Potraw }\end{array}$ & $\begin{array}{l}\text { End of August/beginning of September (IIII, IV, V), around } \\
\text { The Nativity of the Blessed Virgin Mary 8th of September } \\
\text { (VII) }\end{array}$ & $\begin{array}{l}\text { River grasses (I, IV, VIII); river grasses in front of the river (II); } \\
\text { depressions (VII) }\end{array}$ \\
\hline \multirow[t]{17}{*}{ Grazing } & Cattle & April/May—15.10/01.11 & $\begin{array}{l}\text { smugi }+ \text { biele }+ \text { mineral islands }(I I)+\text { Alnus forest }(I I I) ; \text { grąd } \\
(\mathrm{V}) ; \text { Alnus forest }(\mathrm{VI})\end{array}$ \\
\hline & & $15.05-01.11$ & parowy + biele $(\mathrm{I})$ \\
\hline & & In May, before 1st mowing & Mineral islands (VII) \\
\hline & & During mowing time & Alnus forest (VII) \\
\hline & & After 1st mowing & biele $(\mathrm{V}, \mathrm{VII})$; peat meadows $(\mathrm{VI})$ \\
\hline & & After 2nd mowing & River grasses in front of the river (II); river grasses (IV, VII) \\
\hline & Horses & $1.05-15.10$ & $\begin{array}{l}\text { smugi }+ \text { Alnus forest }(I I)+\text { biele }+ \text { mineral islands } \\
(\text { (III); grad }(\mathrm{V}) ; \text { peat meadows }+ \text { Alnus forest }(\mathrm{VI}) \text {; river } \\
\text { grasses }+ \text { biele }+ \text { mineral islands }(\mathrm{VII})\end{array}$ \\
\hline & & $15.05-01.11$ & Mineral islands + biele $(\mathrm{I})$ \\
\hline & & After 1st mowing & biele $(\mathrm{V})$ \\
\hline & & After 2nd mowing & River grasses (IV) \\
\hline & Sheep & $1.05-15.10$ & smugi (III) \\
\hline & & $15.05-01.11$ & Mineral islands + smugi $(\mathrm{I})$ \\
\hline & & After 2nd mowing & river grasses (IV) \\
\hline & & Autumn & Alnus forest + biele $(\mathrm{VII})$ \\
\hline & Pigs & $1.05-15.10$ & smugi (III); Alnus forest (VI, VII) \\
\hline & & $15.05-01.11$ & smugi $(I)$ \\
\hline & Geese and ducks & $1.05-15.10$ & smugi (III) \\
\hline
\end{tabular}

The Roman numerals in parentheses indicate the village: I—Sośnia, II—Pluty, III—Brzostowo, IV—Rutkowskie, V—Kołodzieje, VI—Gugny, VII—Olszowa Droga

the 'river grasses' which were not used as pastures were mown a second time. A few informants stated that the second cut provided even better hay quality than the first cut: first hay was a very good fodder-out of thicker grass, however, the second was better-out of very soft grass (IV). If 'river grasses' were not available to a community, but only the worse quality 'white meadows', then these were also mown once or occasionally twice (V). Mowing in wetlands usually started from the side of the river and was performed by the whole village simultaneously. It engaged people for intensive 2-week-long work.

Natural conditions shaped the development of haymaking methods and defined the used materials. All informants said that depending on grass quality, it was mown either na pokos - 'in swath' (in case of thicker grasses, the haymaker would mow a swath only from one side-mowing always in one direction) or $\boldsymbol{n a}$ zbijaka - to conglomerate' (a technique applied to thin grasses; the haymaker would mow grass from two sides to achieve a thicker swath-mowing in two directions, back and forth). The first technique was the predominant, while the second was used on very poor-quality 'white meadows' (V, VII); grasses in the most distant 'taking', like fifth and further zones (III); or on 'peat meadows' (VI). It was good to start mowing at dawn with the dew when grasses were fresh and not dried by sun (VII). During dry and sunny weather, hay did not require turning. When hay dried out, women raked it and formed kopy (small haystacks). Usually, a couple of people would bring these small haystacks to the final large haystack on nosidta (two special wooden rods around three metres long used like a stretcher). Sporadically, hay was not carried by a couple of people but situated with a rope on one wooden pole that was attached to a horse which then carried it to the stack.

A haystack was preferably built on a mineral island if it occurred in the owned plot of meadow, or, as was usually the case, in the middle of the plot (as the most easily reachable and optimal location). As only the haystacks from the meadows close to the settlement were transported on a boat to stable but in most cases stayed in wetlands for the next few months until the winter, a special platform was built under the stack to prevent hay from being flooded and decaying. A few expressions were used for these platforms, such as art (VI, VII), hart (VI), podzisko (II, III, IV, V), tożysko (I, V). The structure had a circular shape. It was constructed from any available material-either stones (II, IV) or embedded wooden small poles, ca. $50 \mathrm{~cm}$ in height. These poles were 
additionally covered with branches (see Fig. 7). In wintertime, when frost made the meadows accessible, people would bring available material needed for platform structures, such as sand (IV), stones (II, IV) or branches (VII): in summer, it was challenging for us to bring all these branches when the water was everywhere (VII). The platform structures were so high that when a man had to come to a stack with a boat (because water was so high) the hay was still not touching the water surface (IV). The final stack was about $4 \mathrm{~m}$ high and $4 \mathrm{~m}$ in diameter. It was built by two people who, by giving to a stack a proper shape and arrangement of external hay, provided it with the necessary stability and waterproofing. In the LBB, all haystacks were ballasted by four heavy poles interposed on top of the whole structure. These poles had various names such as gręzidta (II, III), koźliny (IV), chlusty (V, VI, VII), zimówki (I). Various tree and shrubs species were used as material, depending on what was available (Table 5). If wood was not available, they were replaced by ropes made out of hay. As a rule, hay was transported from stacks to the stable on a horse-drawn sleigh in winter, when the wetlands were frozen.

\section{Local plant knowledge}

The local community distinguished more than 50 folk generic taxa (ethnospecies) among the plants growing in wetlands (Table 5). Some of the plants are named by and aggregated into groups that apply to a higher systematic domain such as a life form. As a rule, people differentiated groups of 'grasses,' 'shrubs' and 'trees'. Part of wetland species, which, according to people, do not have any farming value, were categorised as ziota 'herbs', rodzina ziót 'herb family' by a few knowledgeable informants. These plants, usually with colourfully blossoming flowers, frequently did not have generic names besides those used for medicinal purposes. This group of plants seems analogous to 'grerb'-small herbaceous species, a life form distinct from grasses. Species with broad leaves growing on the water were sometimes classified into a group of kacaki:formerly, people named them kacaki (III). Knowledge about these species was usually related to fishing, with the exception of Menyanthes trifoliata, which was a salient ingredient of hay. People also identified other generic taxa, which are not affiliated into any higher category.'Grasses' (which also comprise some other grassland monocots such as sedges and rushes) are the utmost salient species in farming, therefore, there was the most extensive knowledge related to them. They are the prevalent ingredient of hay, dominate the landscape, and form the majority of the biomass collected from wetlands, so even if some of these ethnospecies did not have high fodder value, knowledge about them developed nevertheless. Similarly, 'shrubs' and 'trees' occurring in the area were salient species used as a source of timber and material for various necessary tools and constructions in traditional farming practices.

\section{Folk plant classification}

A single folk generic taxon may refer to multiple botanical species of a similar habitat (sitorz Juncus spp., Eleocharis palustris), similar morphological features (hoszczka Equisteum fluviatile and Equisetum palustre) and/or similar hay value (rzeżucha Carex elata, Carex acutiformis etc.). Sometimes one ethnospecies may comprise a few scientific species; however, it was not the whole plant individual that was identified as a folk taxon, but only the parts without flowering stems in the case of mózga Alopecurus geniculatus, Agrostis stolonifera etc., or only the blossoming parts of the plant in the case of miotta Poa palustris etc. The taxa of the 'grasses' category were predominantly distinguished by comparing their different morphological features (width of the leaves, height, or shape of the stem). In this way, the subgroup of trawy mieczowate 'sword-like grasses' (bluszcz Glyceria maxima, tatarak Acorus calamus, kosak Iris pseudacorus) was distinguished by a feature of the relatively broad leaves, which are much broader than those of other wetland 'grasses'. People stated that some of the wetland taxa have comparable, twin plants occurring in a habitat other than wetlands, usually arable fields. These species were phrased by secondary lexemes (e.g. hoszczka polna Equisetum arvense, miotta polna Apera spica-venti), therefore, they might be classified as belonging to a lower domain-specific taxa-of the ethnospecies. Sometimes a single botanical species had clear regional semantic variations. Phalaris arundinacea was called jeczmianka by inhabitants from villages on the left bank of the Biebrza River, whereas inhabitants of the majority of the villages on the right riverbank and southern part of the LBB claimed that they have never heard this name and call this plant jemiota/niemiota. Generally, characterisations of the species derives from traditional haymaking experience with the plants, e.g. what it was like to mow the plant with a scythe, to dry it, to rake it, to make a haystack out of it; how much hay the plant provides; how the plant was used during haymaking, etc. (Table 5).

\section{Distribution of species knowledge}

When asked to freely list plant species growing in wetlands, people the most often cited rzeżucha (Carex spp.)-88.6\% of informants, then mózga Agrostis stolonifera, Glyceria fluitans etc. $-77.1 \%$, Glyceria maxima-74.3\%, Phalaris arundinacea-68.6\%, trzcina Phragmites australis-65.7\%, hoszczka wetland Equisetum spp.-65.7\%, Acorus calamus-57.1\%, bobrek Menyanthes trifoliata-54.3\%. A quarter of 


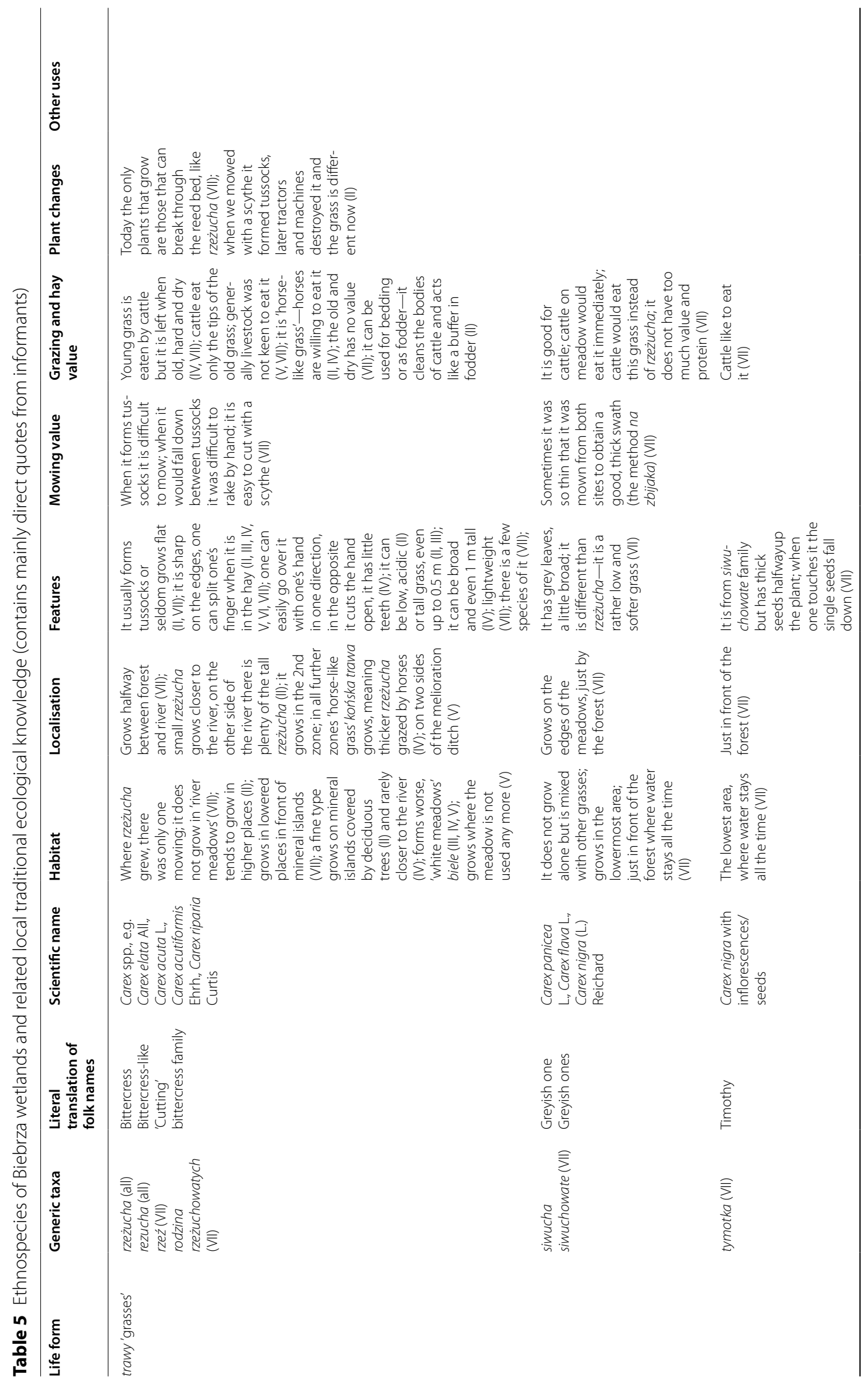




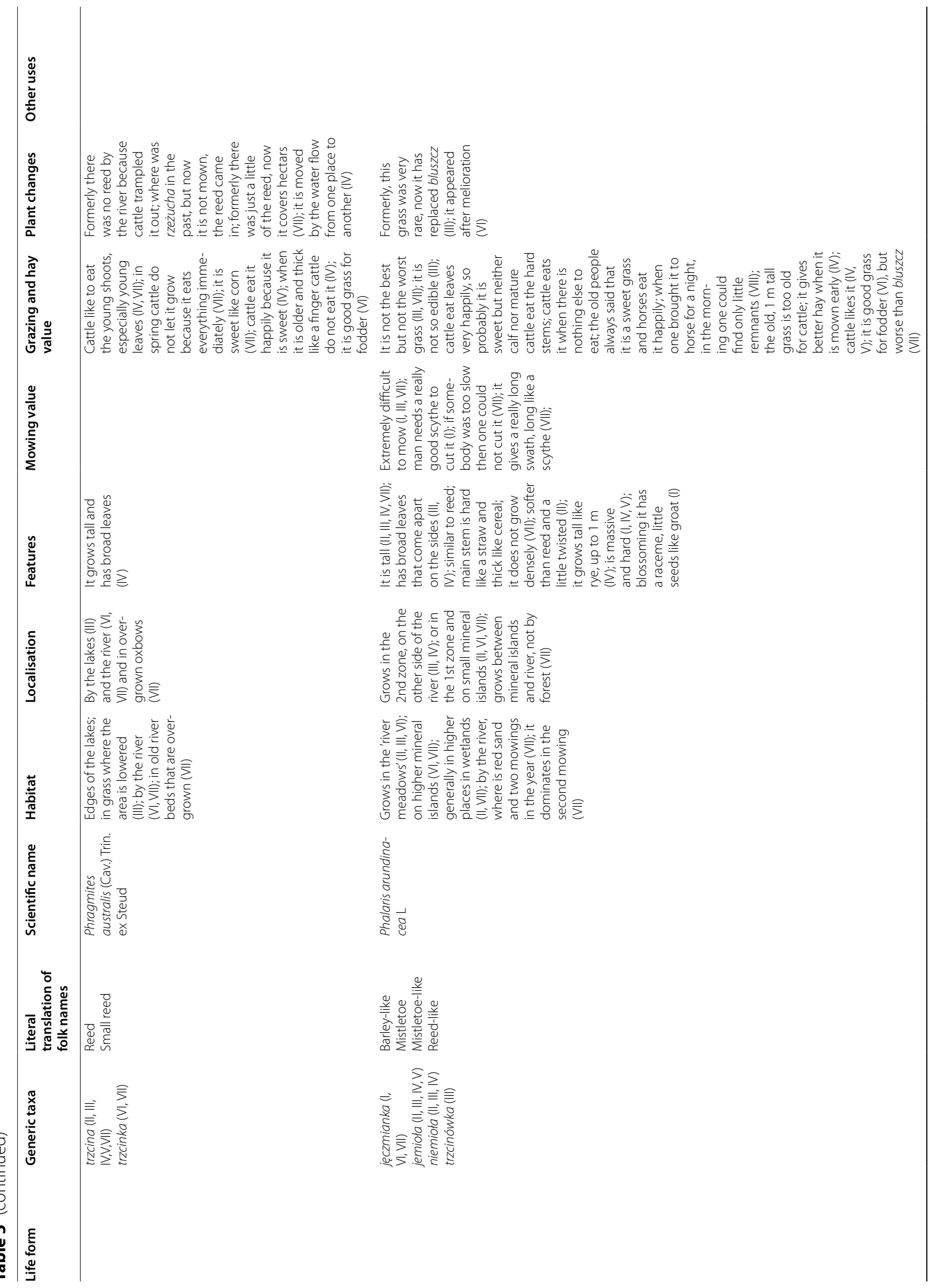




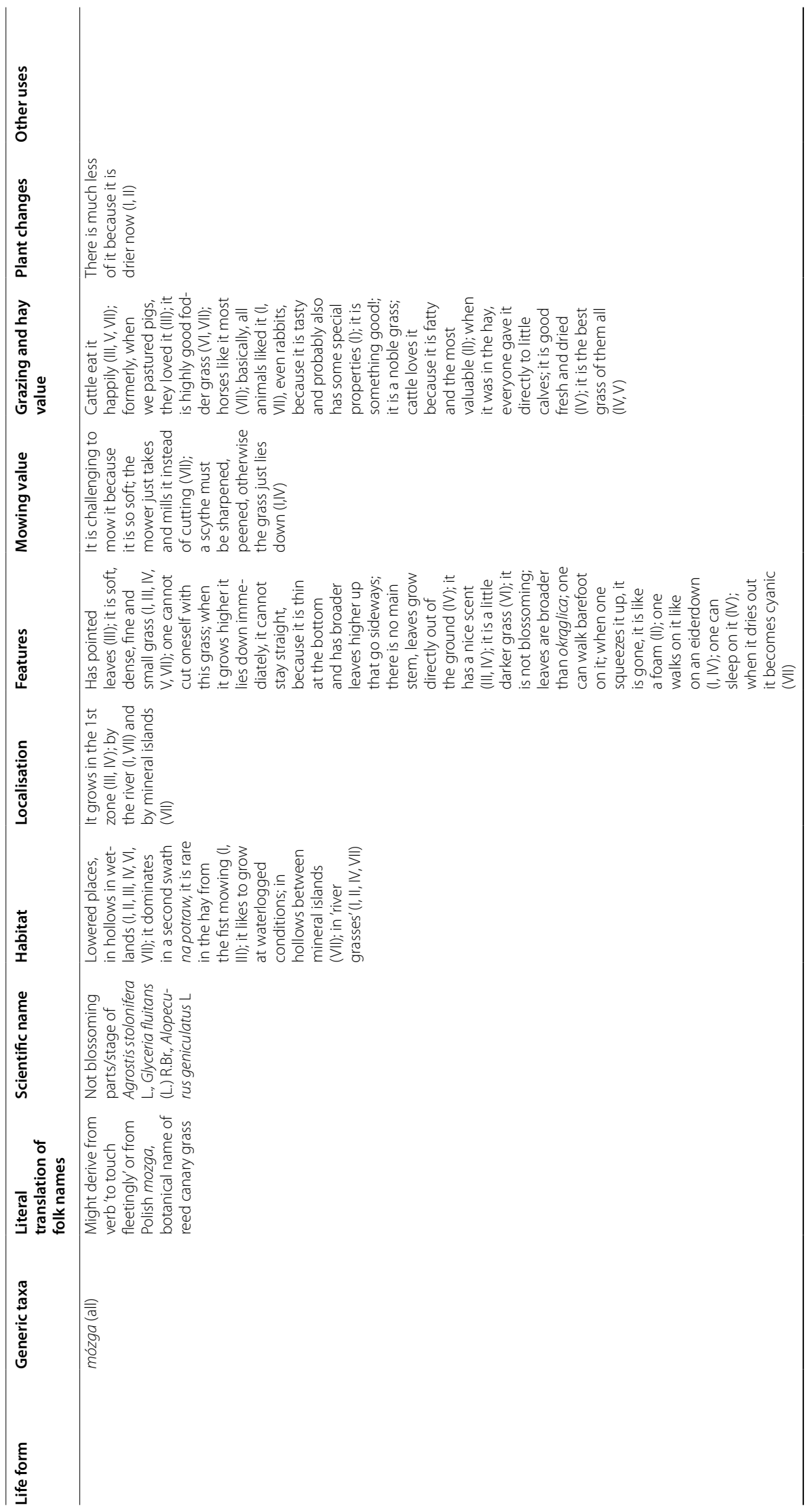









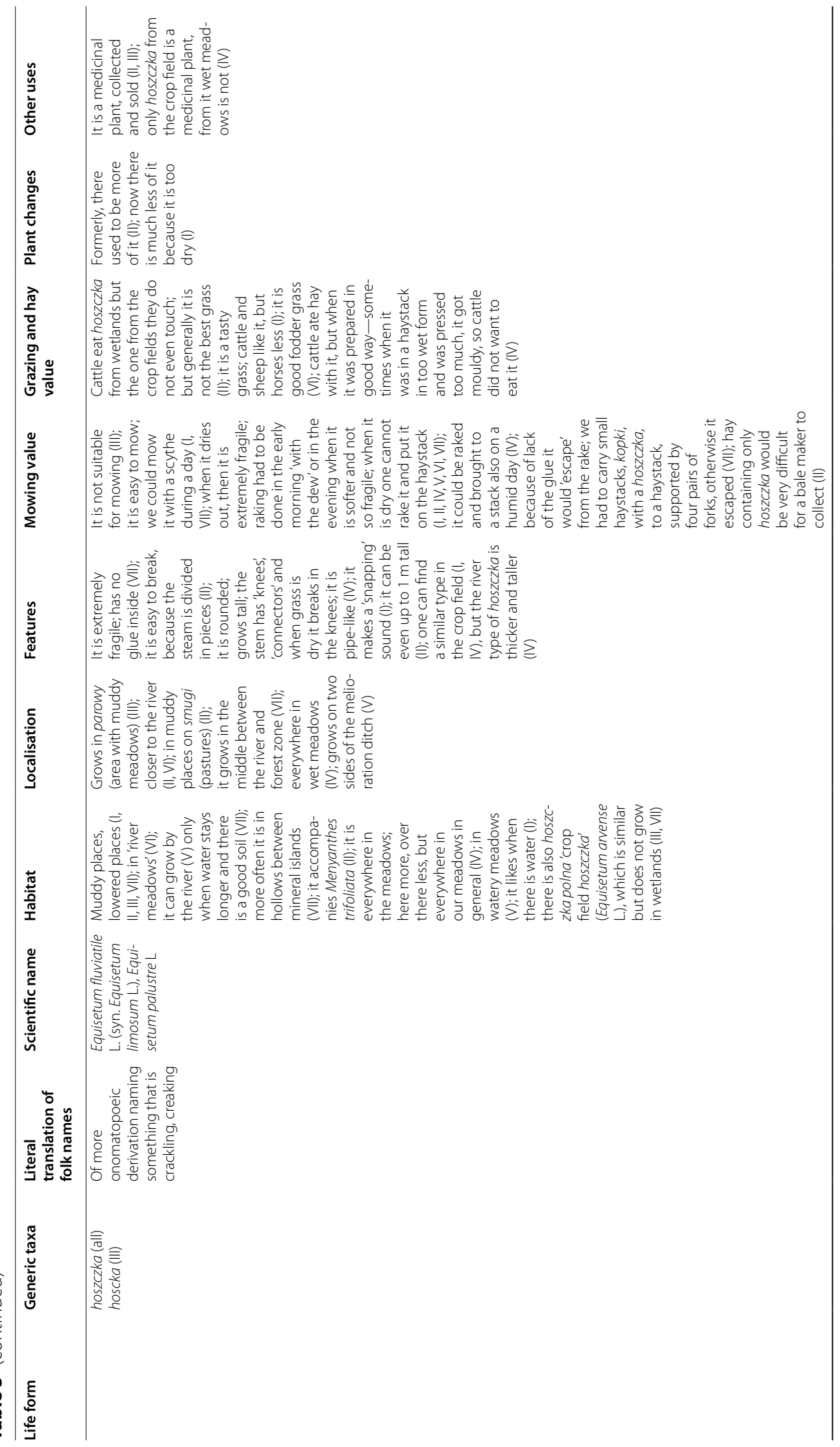




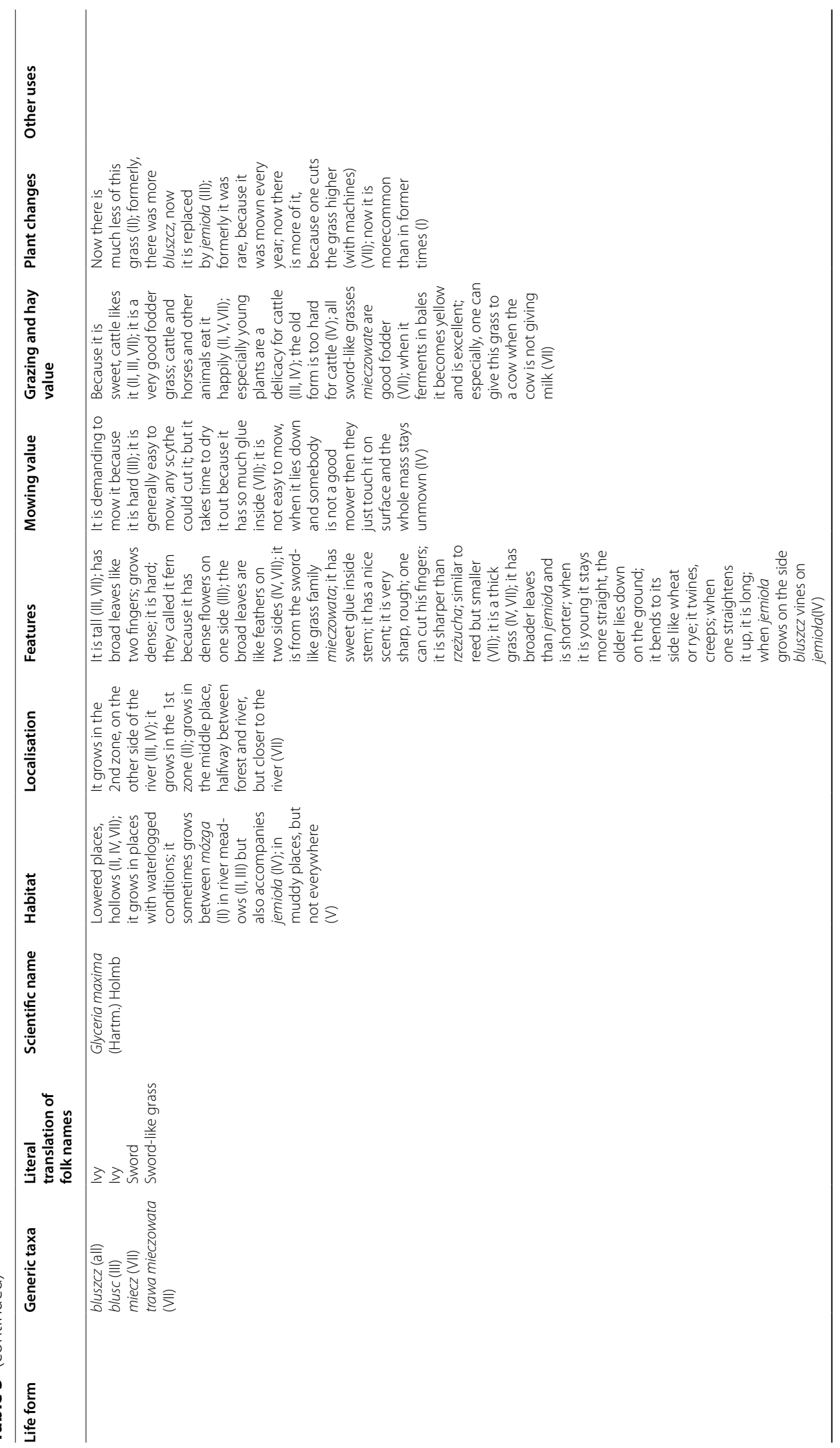




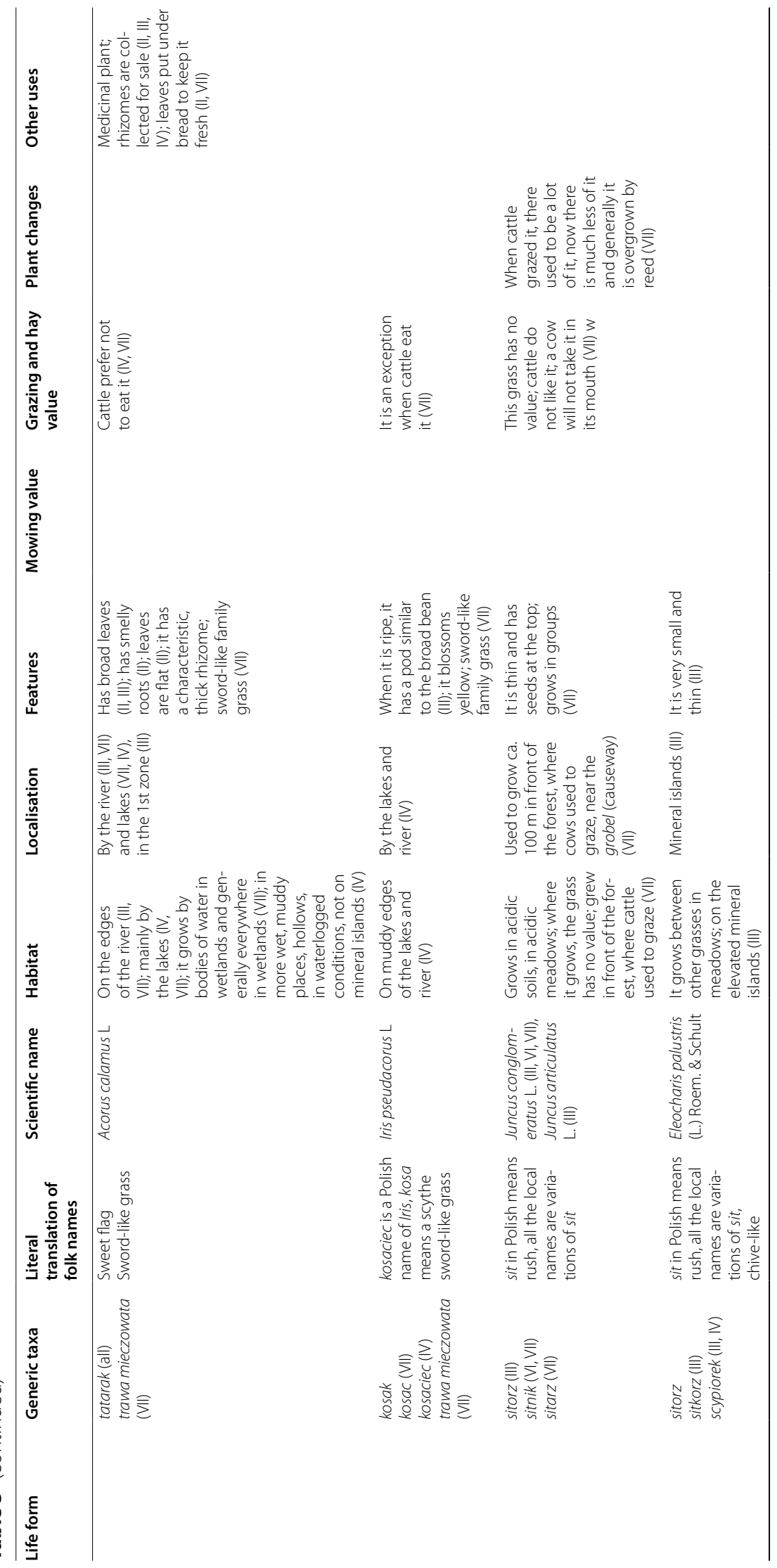




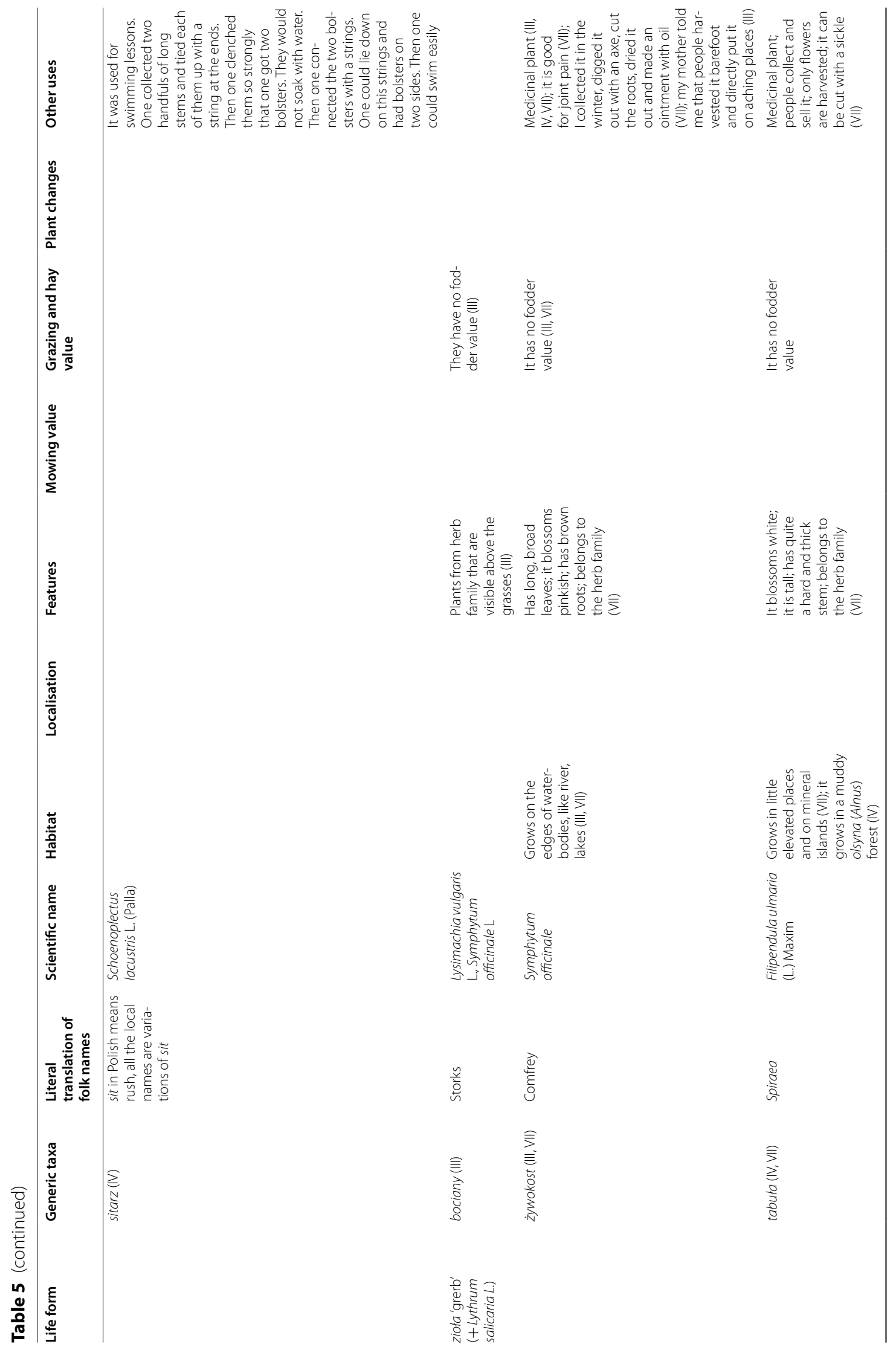




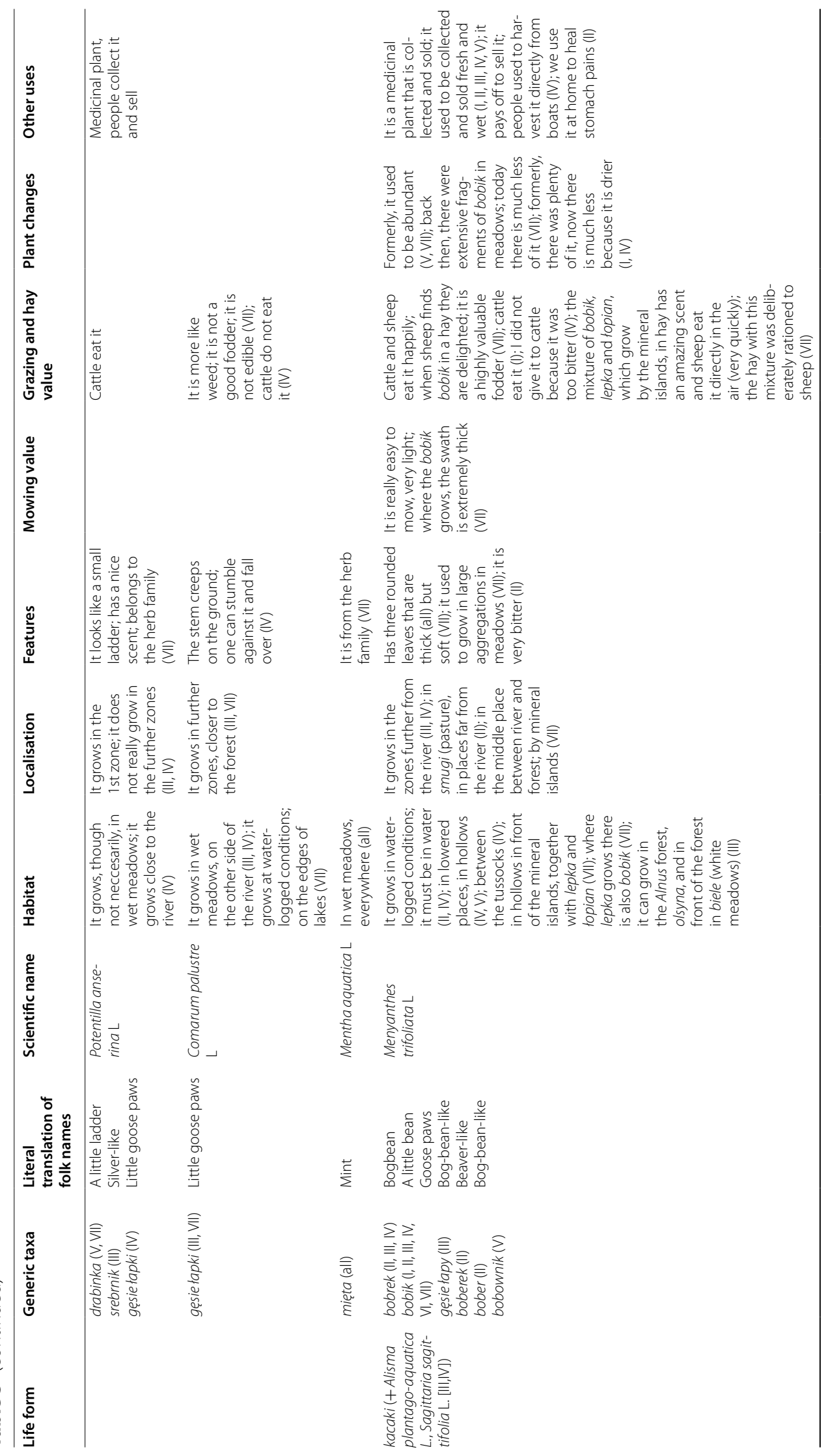




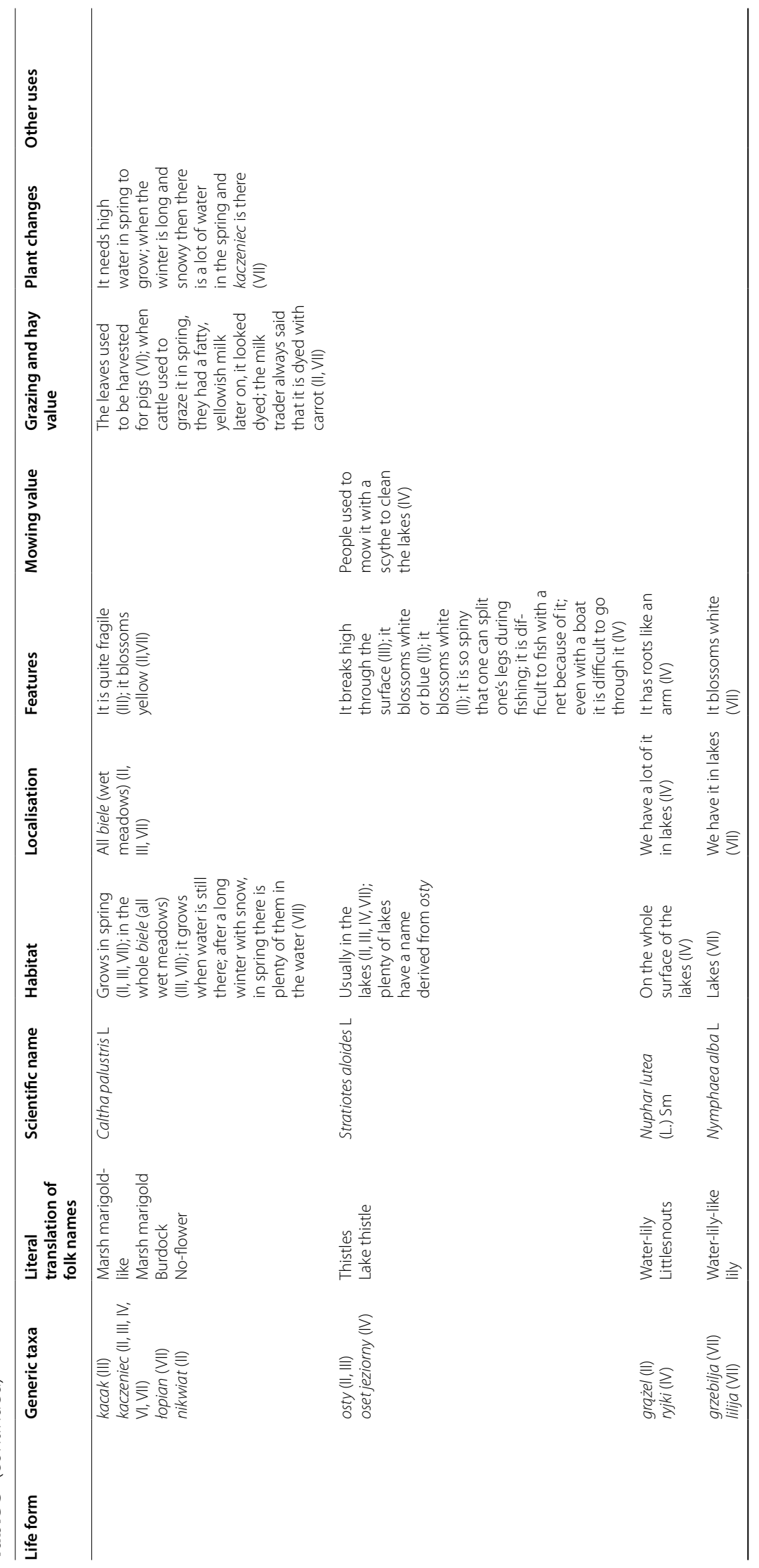




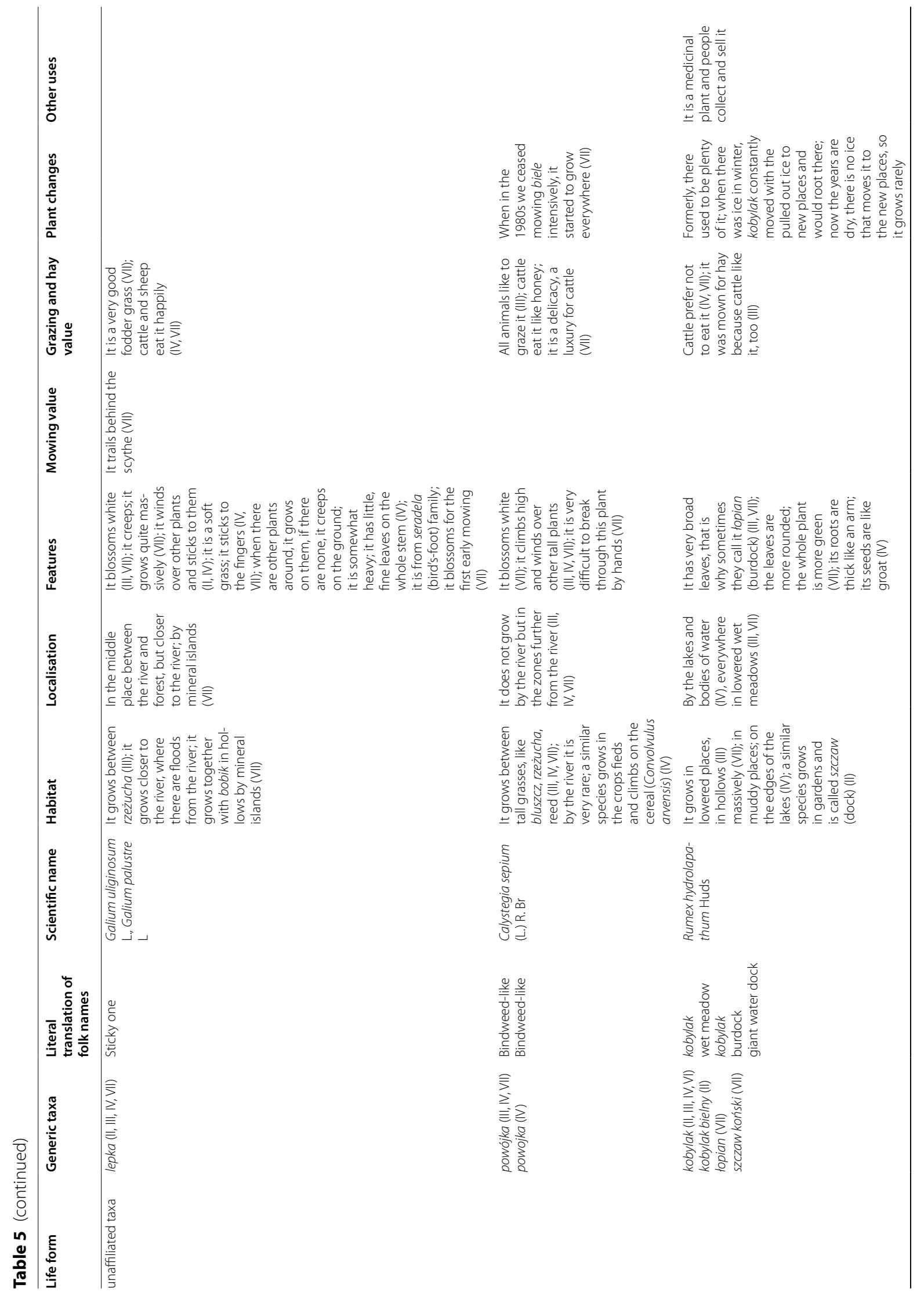




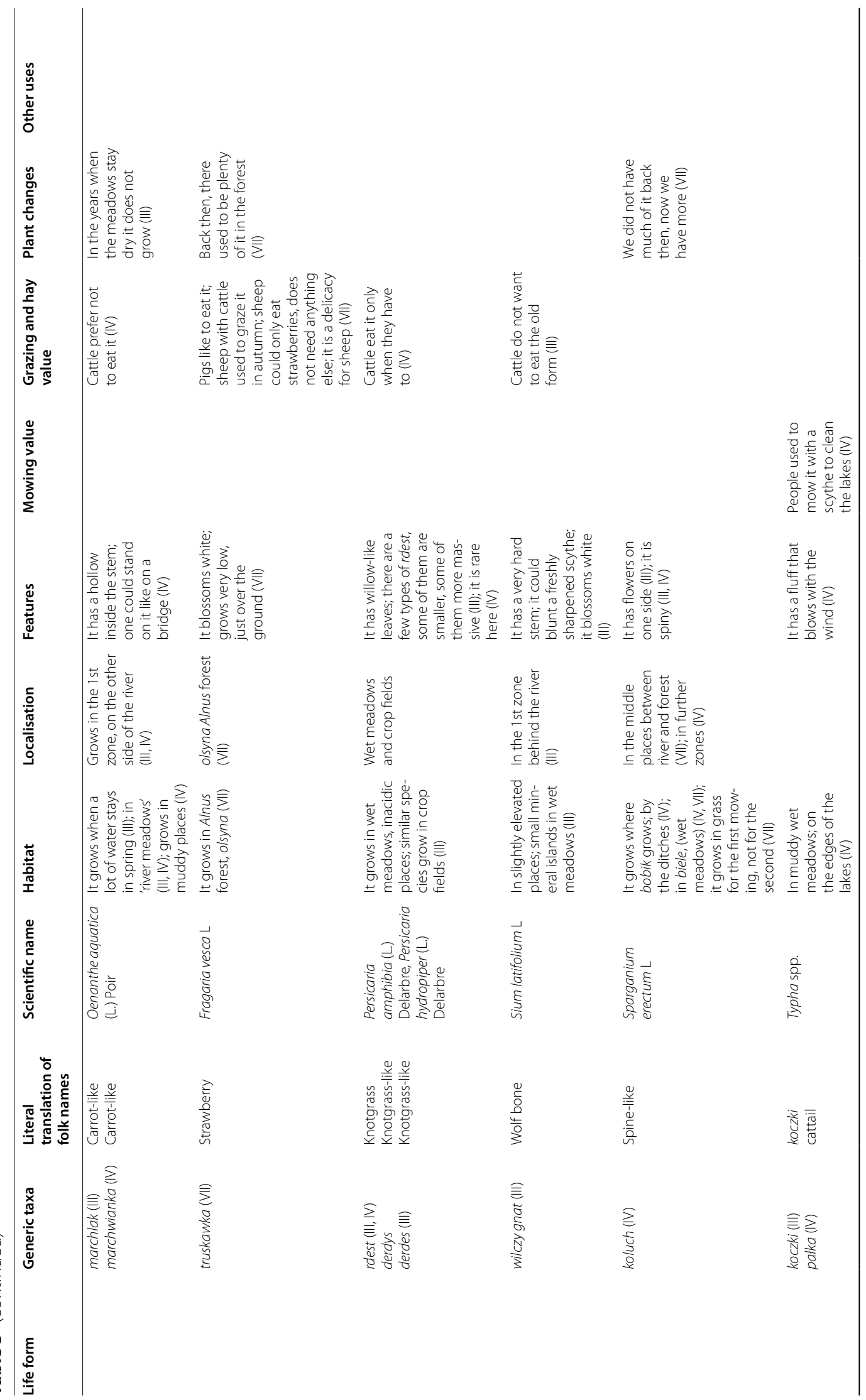









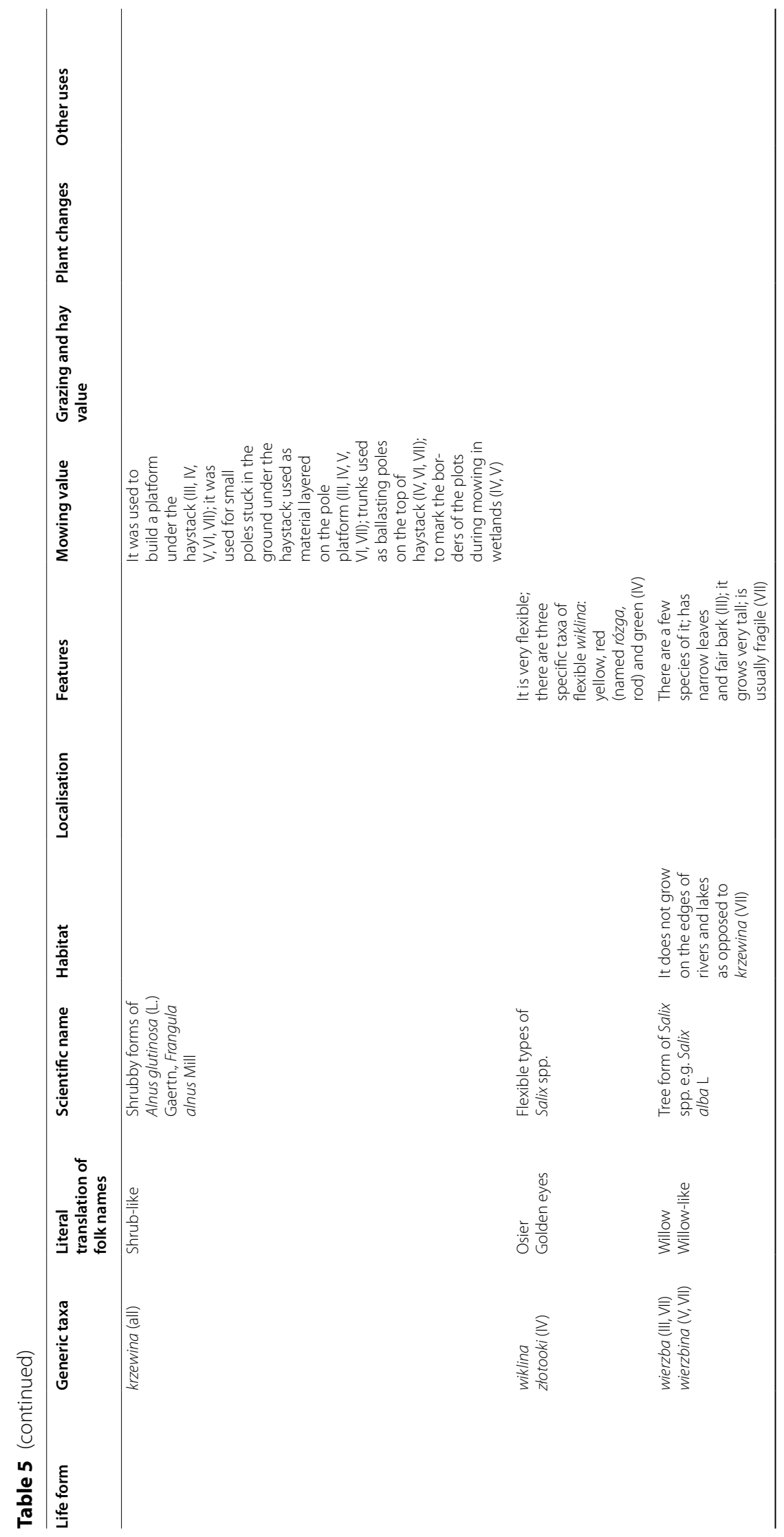




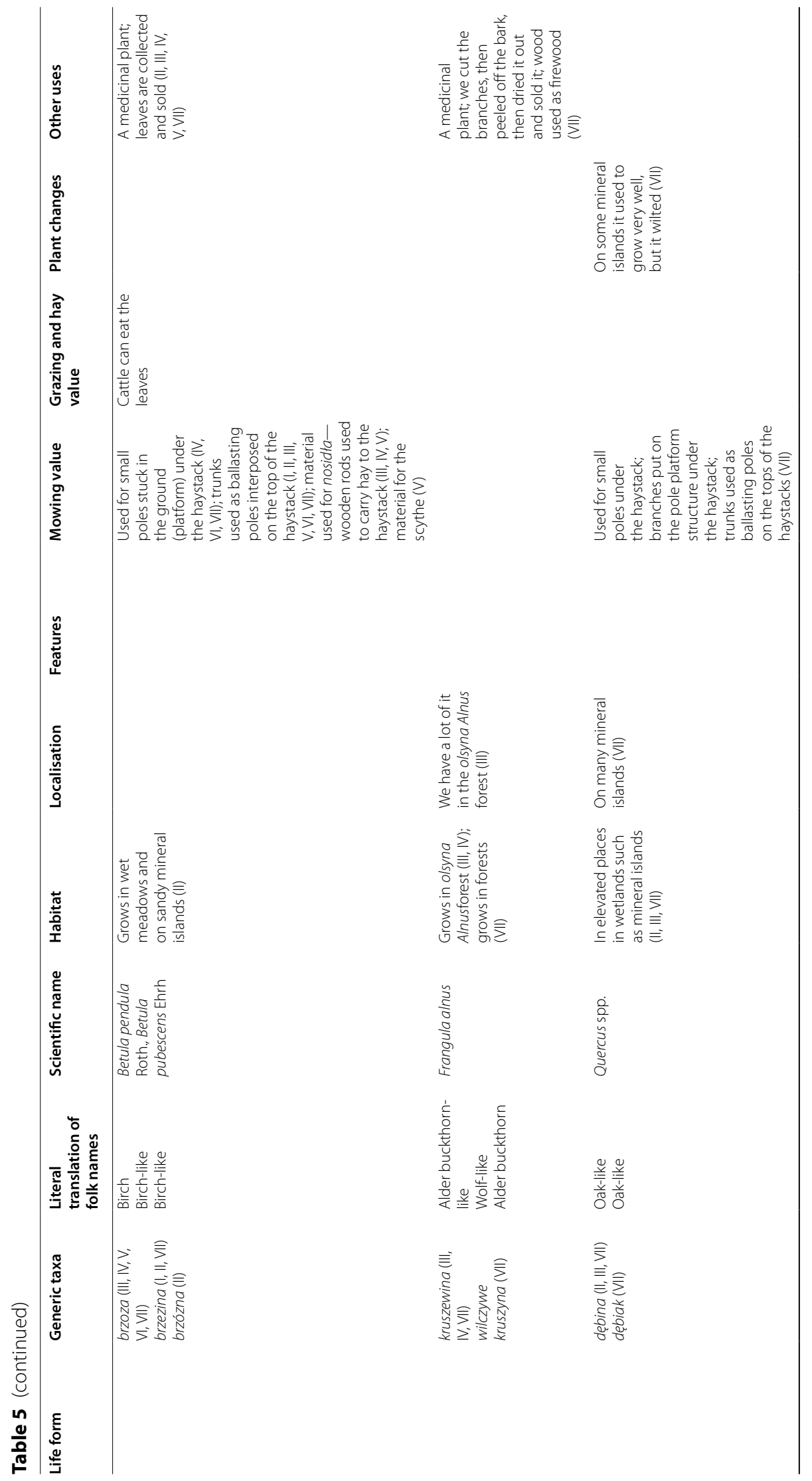









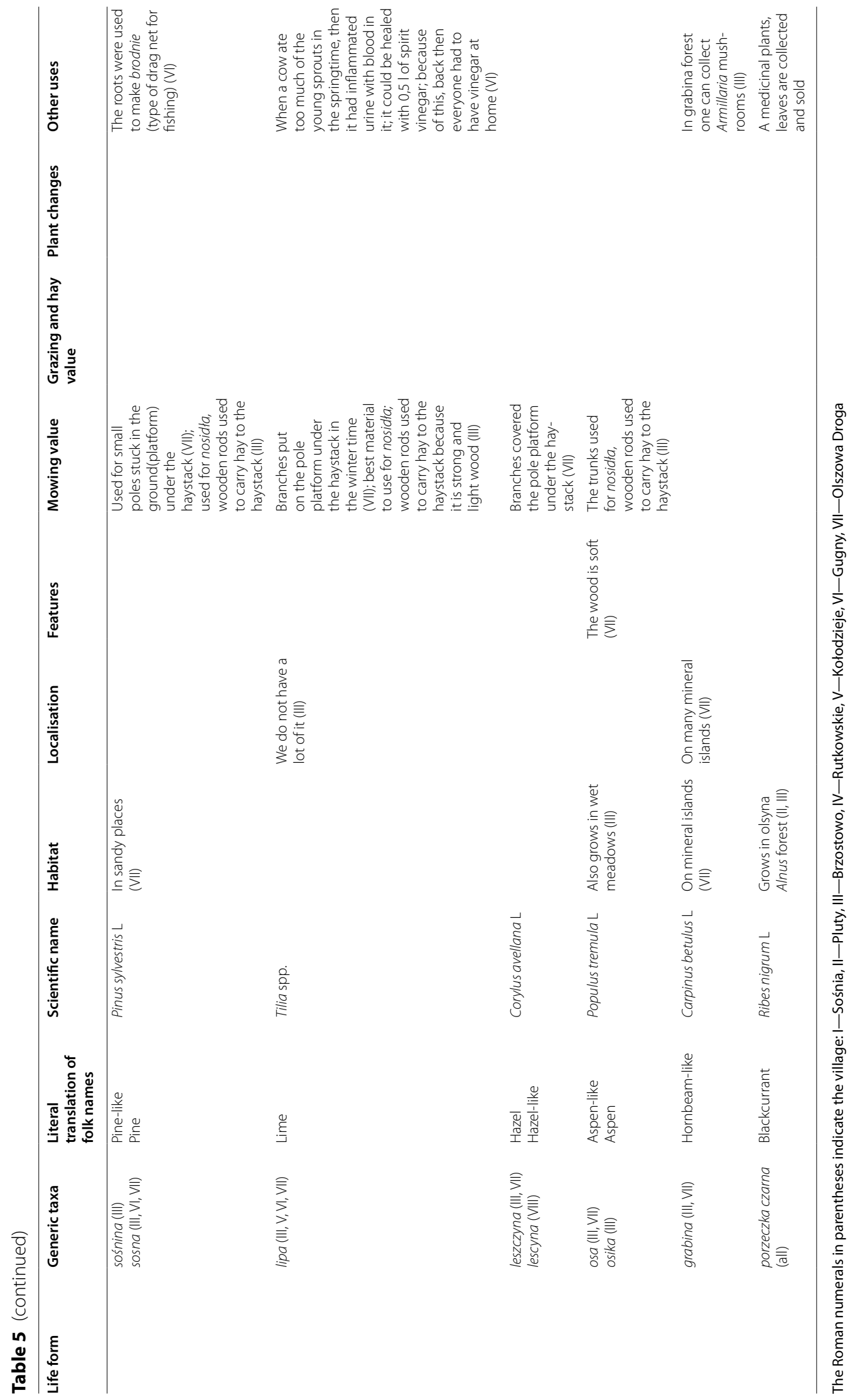


the informants mentioned okraglica Carex appropinquata etc. and kobylak Rumex hydrolapathum. Slightly fewer informants listed mietlica blossoming Poa palustris etc. and kaczeniec Caltha palustris, and one fifth of the informants listed: lepka Galium uliginosum, G. palustre, osty Stratiotes aloides, mięta Mentha aquatica, powójka Calystegia sepium and drabinka Potentilla anserina. Other ethnospecies were mentioned less often. People did not usually mention shrubs and tree species in this part of the interview, as these plants were not included in hay.

\section{Species in habitats}

Even if the landscape of the wetlands in the LBB seems to be continuously flat, local people in the first place described the habitat of the species by differentiating lower and higher places. For some plants, like Glyceria maxima, dotek 'lowered place' is applied to, the habitat that is lowered in relation to the level of the river. However, more often dotek related to hollows in wetlands-places where water used to stay longer, which are often differentiated from higher mineral islands and high structures formed by the plants, like tussocks. According to informants, in the hollows in wetlands there grow: Phragmites australis, mózga A. stolonifera, etc., hoszczka wetland Equisetum spp., Glyceria maxima, Acorus calamus, Menyanthes trifoliata, lepka wetland Galium spp., Rumex hydrolapathum, olszyna Alnus glutinosa. Rzeżucha Carex spp. generally grows in higher places (forms tussocks), but also in lowered placed in front of mineral islands. Only in elevated places Phalaris arundinacea, okraglica Carex appropinquata, C. diandra, mietlica blossoming steams of Poa palustris, Deschampsia flexuosa, tabuta Filipendula ulmaria, sitorz Eleocharis palustris, Juncus spp., wilczy gnat Sium latifolium, dębina Quercus robur, and grabina Carpinus betulus occur. Some of the habitats were defined by the occurrence of accompanying species. For instance, a few informants said that: Calystegia sepium grows between 'tall grasses' like Phragmites australis, Glyceria maxima, rzeżucha Carex spp.; Menyanthes trifoliata can grow in hollows formed in front of mineral islands together with lepka Galium spp. and Rumex hydrolapathum, providing a specific sort of very high quality hay good for sheep; Glyceria maxima can grow together with mózga or with Phalaris arundinacea. Species like mózga and Phalaris arundinacea dominate in hay from the second mowing. Conversely, koluch Sparganium erecum prevails in hay from the first mowing.

\section{Species in the landscape}

The location of certain plants within the wetland landscape is embedded in the local partitioning of the landscape (Fig. 4). As informants said, nearby the river and along waterbodies there grow Acorus calamus, Iris pseudacorus, Phragmites australis and Typha spp. The 'river grasses' of the 1st and 2nd zoning are generally dominated by mózga Agrostis stolonifera etc., wilczy gnat Sium latifolium, marchlaki Oenanthe aquatica, Potentilla anserina and hoszczka wetland Equisetum spp. A bit further away from the river, the second zone of the 1 st zoning and the first zone in 2nd zoning are mainly constituted by Glyceria maxima and Phalaris arundinacea. In zones further from the river (1st zoning) or in between the 1st and 2nd zone (2nd zoning), where the 'white meadows' are, rzeżucha Carex spp. prevails, accompanied by Menyanthes, lepka wetland Galium spp., Calystegia sepium, gęsie tapki Comarum palustre, Sparganium erectum. The second zone (in 2nd zoning, VII) is dominated by siwucha Carex nigra, C. flava etc. and tymotka flowering Carex nigra, occurring directly in front of the Alnus forest. Similarly, in the furthest zone from the river, by Alnus forests in the 3rd zoning (VI), okraglica Carex appropinquata, C. diandra prevails on the 'peat meadows'. Many species can occur in Alnus forests, and include kruszewina Frangula alnus, czarna porzeczka Ribes nigrum, truskawka Fragaria vesca, Caltha palustris and others.

\section{Species in management}

Some species indicate a type and quality of vegetation that determines an area's management. Vegetation constituted mainly by rzeżucha Carex spp. was traditionally mown early, once a year, whereas 'river meadows' dominated by Phalaris arundinacea were traditionally mown twice a year. According to the informants, all species called sitnik, sitarz such as Juncus spp., Eleocharis palustris etc. indicate acidic soil; when mown, they provide very bad quality hay. Okraglica Carex appropinquata etc. and siwucha Carex nigra etc. indicate vegetation that is not dense enough to be mown using the common method na pokos-from one side-and therefore should


isfyingly thick swath.

\section{Value of species used for hay}

People expressed the high fodder value of a plant through its positive association with good quality and tasty food. The most valuable plants were most often described as stodkie trawy 'sweet grasses', less often ttuste trawy 'fatty grasses', or majace dużo biatka 'being rich in protein. Conversely, plants that give low quality fodder were 
defined by all informants as kwaśne trawy'sour grasses'. A few informants named them końskie trawy 'horse-like grasses', indicating that horses, believed to have the highest tolerance for different types of fodder, are more happy to eat those plants. Assumptions about the fodder value of the plants were based on observing if livestock eats the plant or not, how quickly it eats the plant, and what preferences the livestock has (for which species it reaches in the first place). Based on those observations, people also assessed the quality of the plants by comparing them to each other. When analysed qualitatively, the order of folk taxa ranked according to the value attributed to the given fodder by local people (based on observed cattle preferences) would be as follows. Mózga Agrostis stolonifera etc., Menyanthes trifoliata, lepka wetland Galium spp. and Calystegia sepium were included in the best fodder unanimously by all informants. Caltha palustris in the spring and Fragaria vesca in the autumn provide very good seasonal fodder. The next best in terms of value would be Glyceria maxima, mietlica blossoming Poa palustre etc. and Potentilla anserina, which are eaten by cattle in any form. Meanwhile, Phragmites australis is a highly valuable plant only when it is young, and cattle does not eat it in the old stage. Similarly, Phalaris arundinacea could be ranked as a fodder plant of moderate value, since cattle eat only the very young plant or its leaves, avoiding the hard stem. However, it is good fodder for horses. Some but not all informants evaluated siwucha Carex nigra etc., tymotka blossoming Carex nigra, hoszczka wetland Equisetum spp., Rumex hydrolapathum and Sium latifolium as good fodder. Next in rank could be rzė̇ucha, a voluminous ethnospecies covering many Carex species. It was usually classified as low-quality fodder which, when young, can be alternatively eaten by cattle. The next could be rdest wetland Persicaria spp. and okraglica C. appropinquata etc.-plants eaten by cattle only when the animals have no choice of other fodder. Finally, there would be the group of plants which, according to people, are seldom eaten, like Acorus calamus, Iris pseudacorus, Oenanthe aquatica, sitorz Juncus spp. etc., bociany Lysimachia vulgaris etc., Comarum palustre, and tabuta Filipendula ulmaria. The favourite plants for other livestock were as follows: mózga $A$. stolonifera etc. is a delicacy for many animals, including cattle (especially calves), horses, pigs, sheep, and rabbits; Menyanthes trifoliata, lepka wetland Galium spp., Rumex hydrolapathum and Fragia vesca are the favourite fodder of sheep, whereas Fragaria vesca and the leaves of Caltha palustris are a delicacy for pigs.

\section{Increaser and decreaser species}

The older informants shared the changes they observed in plant occurrence during their lifetimes. People noticed that in recent years a drought led to a decrease in the abundance of mózga A. stolonifera etc., hoszczka wetland Equisetum spp. and Menyanthes trifoliata. People also observed that the occurrence of Caltha palustris, Oenanthe aquatica and Rumex hydrolapathum is depending on the temperature and snow cover in winter (directly related to amount of water in spring) - the colder and snowier the winter, the more abundant they are. According to many informants, in recent years, Phragmites australis started to prevail in vegetation. Firstly, they argued that, it used to be less common in the times when more cattle grazed in wetlands and trampled it. Secondly, it replaced rzeżucha Carex spp., which does not tolerate mowing with machines, because they destroy its tussock structure. Discontinuation of mowing led to the increase of krzewina shrubby Salix spp. and Calystegia sepium. The increased abundance of Phalaris arundinacea was noticed in two villages; in one of these, the plant was observed to have replaced Glyceria maxima. In the two other villages where regular mowing by the river had been abandoned, more abundant Glyceria maxima was observed, together with an increase in the abundance of Sparganium erectum in one of the villages. Two informants spotted a local decrease of the okraglica Carex appropinguata etc. population, which seems to have been replaced by Deschampsia flexuosa.

\section{Shrubs and trees}

Shrubs and trees used to serve as a source of timber for wintertime. They were also used to make e.g. platforms under haystacks, ballasting poles to cover haystacks, rakes, scythes, rods to carry hay, etc. As a rule, the type of the shrub or tree used, especially when it came to building a platform under a haystack, depended simply on its availability in the landscape. However, $77 \%$ informants indicated thin trunks of Picea abies as the best source of wood for rods used to carry kopy 'small haystacks' to a haystack. Spruce wood was described as lightweight and resistant, therefore perfect to carry heavy'small haystacks.' Alternatively, birch or alder wood could be used. As many as $71 \%$ of all informants indicated a freshly cut small birch tree as suitable to be used as a ballasting pole on a haystack due to its heaviness and elasticity, which made it possible to tie small branches together on the top of a stack. As many as 50\% of informants also indicated alder as suitable for this purpose, however two people mentioned that it was a bit fragile. As many as $36 \%$ of informants listed krzewina shrubby forms of Salix spp., Frangula alnus etc.; however, they reasoned it was used only due to its common availability. Mostly hard species of krzewina shrubs, mainly Salix spp., then alder, birch, oak and pine were recommended for the small pales in 
haystack platforms. Branches of krzewina shrubs, mainly Salix spp., were commonly used as padding material.

\section{Discussion}

\section{Local traditional knowledge of wetlands}

Even though traditional land use of wetlands in the Biebrza Valley has been gradually ceasing since 1960s, the interviewed members of local community, particularly male representatives of the older generation, shared ecological knowledge on plants, landscape, and traditional management that was complex in dimensions and rich in detail. Women, being only partly engaged in traditional haymaking (hay raking and transporting), had much less wetland plant knowledge. As studies of Fawzi [64] and Mustonen [3] indicate, women can also be relevant knowledge holders, as long as they are fully engaged in land and resource management. A comparison of our results on traditional farming practices with the findings of Kiryło [78] from the same area revealed already forgotten elements of knowledge (like herding with a dog, recognition of more habitats). This fact as well as the limited knowledge on plants and livestock grazing preferences amid currently studied younger farmers confirm that since extensive traditional practices are being discontinued, knowledge on nature and its management is no longer generated, which leads to its degradation and loss $[64,65]$.

We assume, based on plant knowledge shared by older farmers, containing mainly qualities of plants in the context of personal farming experience, that direct contact with plants during haymaking (hand mowing with a scythe, hand raking of hay, building haystacks) and pasturing various livestock in wetlands are crucial factors in knowledge development. The more distanced the farmers are (literally-by machines), the poorer their knowledge, as we can see from the example of young farmers. Similarly to cattle herders [102, 103], farmers in the Biebrza Valley characterised plant ethnospecies by habitat, palatability and the preferences of different type of livestock, however they also added haymaking observations. Interesting remarks on assessing the fodder value of plants by traditional pig keepers (svinjars) 'through the mouths of pigs' [104] have been affirmed in the Biebrza Valley, where farmers do the same but 'through the mouths of cattle', which were the predominant type of livestock grazing in this area. Such knowledge evolves when farmers extensively observe livestock grazing in wetlands or consuming hay.

The basic division of plants into two opposable categories, the 'sweet' (palatable, preferred) and the 'sour' (unpalatable), is an old distinction among Polish peasants $[105,106]$. It seems that the quality of hay assigned to the plant depends on the available vegetation type.
For instance, cattle with access only to wetland vegetation highly prefer species like Glyceria fluitans, Agrostis stolonifera, Glyceria maxima [our study, 30, 34], whereas those grazing in the saline steppe with various drier habitats that include palatable Festuca grass would graze such species as alternative fodder in drought time [102].

\section{Knowledge on landscape and vegetation}

The local, zonal perception of the wetland landscape is comparable to the scientific division into five vegetation zones in the LBB. However, the local community's perception is strongly associated with management practices and hay quality, whereas the scientific division is based on vegetation type that is collateral to the river and connected with the dynamics of the Biebrza River flooding and groundwater flow [95]. In addition, wetland landscape is seen in its vertical dimension, having elevated and lowered places, which are the main criteria of defining folk plant habitats. Although the landscape of the Lower Biebrza Basin is extremely flat when seen from a distance, in fact it includes slightly higher sandy mineral islands [74] and elevated areas on the river edges [95]. Both a horizontal zoning pattern as well as a mosaic of elevated and lowered places have practical meaning for farmers and differentiate management units (of various grazing and mowing regime). Similarly the traditionally managed lowland floodplain of the Sava River in Lonjsko Polje Nature Park in Croatia consists of micro-depressions and micro-mountains formed by water flow, creating different habitats and vegetation [26]. We identified a modest number of wetland landscape elements in the inhabitants' narratives compared to numerous folk habitats recognised in mountainous areas [107]. This is most likely a result of the uniform landform [108], the relatively species-poor vegetation of floodplain and fen meadows in the Biebrza Valley [109] and the fact that part of the knowledge might be already eroded when comparing our results with the findings of Kiryło [78].

\section{Wetland management practices}

The traditional management regime in the Biebrza Valley was first of all flexible and conditioned on water level, similarly to management of the floodplain of the Sava River [26]. The first day of mowing was more or less fixed by church holidays-a marker of important activities associated with plants all over Poland. For example, Assumption Day and Corpus Christi Octave are days when herbs are blessed. They remind people to collect particular species of medicinal plants $[110,111]$. The traditional farming calendar additionally depended on the location of the village, available habitats, vegetation, and type of livestock. The spatio-temporal management had a mixed character (grazing and mowing), as in floodplains 
of the Sava River [26]. In times of traditional farming all wetlands (besides forest) in the Biebrza Valley were mown for hay, which enabled scythe mowing. Generally, scythe mowing, introduced in Eastern Europe in the eleventh century $[50,112]$, is considered a major type of land use, which led to the widespread development of open wetlands and highly biodiverse fen meadows in Europe $[32,45,113]$. Open wetlands and forests in the Biebrza Valley were also grazed, mainly by cattle and horses, locally by sheep in the dry autumn season and by fowl on soft meadows by the river. In the 1980s the area was still described as a vast pasture [78]. In contrast to Pannonian wetlands in Central Europe, which were grazed extensively all year round [34], these wetlands were not grazed in winter (because of snow cover) or in summer, when they were intended to produce hay (at that time Alnus forest became alternative pasture). It is worth mentioning that in terms of creating open wetlands, in Europe, grazing by cattle is a 5-7 thousand-year older land-use type than mowing [32]. Pig grazing in wetland forests, which was locally practiced in the Biebrza Valley, was ceased in ca. 1970s. This practice was not only historically frequent in Europe [33, 34, 114] but present to this day in wet oak forests in floodplains of the Sava River [26, 104, 115].

Haymaking was strictly performed on the owned wetland plots, in opposition to grazing, for which wetlands were used communally, as was traditional also in the wetlands of the neighbouring Narew River [116] and the Balkan Sava River [26]. Interestingly, some of the farming techniques common in Biebrza, like mowing na pokos, the second mowing called otawa, and klepanie kosy na babce, sharpening a scythe with hammer on special iron tool, were common in old traditional practices in other Slavic countries and beyond [114]; likewise wypas kolejkg 'pasturing in queue' $[26,116]$. However, these techniques were usually given different names.

Our study shows that even the poor-quality hay from fen meadows dominated by e.g. Carex appropinquata were used as fodder if no other type of hay was available, in opposition to the statement that historically low quality hay from fen meadows was used only for bedding [32, $33,117]$. However, the farming use of worse quality vegetation in the Biebrza Valley was less complex (usually one mowing, grazing by cattle and horses) than the diversified management regime of highly valued floodplain river meadows (as a rule mown twice, grazed by all possible types of livestock).

\section{Land use changes and conservation challenges}

The intensification of farming in the Biebrza Valley, i.e. the gradual ceasing of scythe use and grazing livestock, led predominantly to the abandonment and overgrowing of wetlands in the LBB. Such land use transitions are considered to be the main threats to the biodiversity of wetlands in Europe [24, 32, 112]. For instance, as in wetlands of the Carpathian Basin [34] and coastal wetlands in Estonia [25], the lack of trampling cattle in the Biebrza Valley resulted in an uncontrolled spread of reed. Since the Biebrza National Park was established, many scientific research and conservation plans have been proposed and undertaken to protect the unique biodiversity and hydrology of the area [71, 118-120]. However, its protection status limited or banned some of the local community's activities. For example, the burning of wetlands is strictly forbidden due to the risk of peat catching fire [121], even though the burning of tussock structured wetlands was traditionally practiced in early spring [78] and controlled burning is recommended as favouring the population of the Aquatic Warbler (a bird species under conservation; [122]). The local community used to extensively hunt for ducks, hares and otters [78], which is currently forbidden and recognised as poaching. Some traditional practices such as removing vegetation in the oxbows are also not continued. However, further research is needed to explore the current management of wetlands in the Biebrza Valley-which is defined not only by the conservation plans of the national park but also by EU agri-environmental regulations-and to propose recommendations on how traditional management and knowledge could be integrated into it.

\section{Conclusions}

The research revealed and documented local traditional ecological knowledge on wetlands' plants, vegetation, landscape and the mixed management regime that is still present among the local community of the Biebrza Valley. It confirms essentially and unquestionably the dominantly cultural origin and character of highly valued ecosystems in the studied area, hence the Biebrza Valley needs to be treated as a cultural landscape in any management endeavours. For this reason, the components and complexity of traditional farming and ecological knowledge of local people should necessarily be taken into consideration as inspiration for conservation management plans in the area, and collaboration with the local community should be undertaken in such activities. The research might give an incentive for further studies in other villages of the Biebrza Valley and in other areas of high environmental value and cultural origin.

\footnotetext{
Abbreviations

LBB: Lower Biebrza Basin; TEK: Traditional Ecological Knowledge; LTEK: Local Traditional Ecological Knowledge; Biebrza NP: Biebrza National Park.
}

\section{Acknowledgements}

We thankfully acknowledge all our informants from the Biebrza Valley who entrusted us with their knowledge and shared it generously and patiently 
(Józef Kojro, Jadwiga Mocarska, Henryk and Halina Dołęga; Stanisław Tyszkiewicz, Józef Ruszczyk, Eugeniusz and Aleksandra Mocarscy, Jadwiga Kozłowska, Bogdan Mocarski, Karwowscy family (Jan, Maria, Renata, Wiesław), Kazimierz Karwowski, Czesław Ramontowski, Jan Grabowski, Jan Mocarski, Kozikowscy family, Eugeniusz Pezowicz, Mieczysław Pisanko, Paweł and Ryszard Lewkowscy, Stanisław and Mariusz Lewkowscy, Mirosław Jabłonowski, Tadeusz Nieciecki and his sons_-Karol and Adam, Leopold and Mirosław Niecieccy, Eugeniusz Wilczewski and his mother, Jan Wejda, Edmund Supiński, Bogdan Jarząbski, Sokołowscy family, Witold and Zbigniew Konopka, Józef and Janusz Rogińscy, Kazimierz and Mirosława Przestrzelscy, Jadwiga Mogilnicka, Józefa Trzaska, Romuald Chrzanowski, Ziemkiewicz family, Stanisław Bartoszewicz) and many other people who helped us find informants and understand the situation in the Biebrza Valley.

\section{Authors' contributions}

IS conceived the study, collected the field data, transcribed the interviews, analysed data and wrote the first draft of the manuscript. PP, ZM and $k t$ supervised the research and added significant insight into the study design, methodology and writing the final paper. All the authors read and approved the final version of the paper.

\section{Funding}

Open Access funding enabled and organized by Projekt DEAL. The research was predominantly financialy supported by the 'PharmaPlants' Project of the University of Applied Sciences in Rottenburg, Germany, funded by the Federal Ministry of Education and Research (BMBF, Germany). The publication fee was funded partly by the Regensburg University and partly from the own budget of one of the authors.

\section{Availability of data and materials}

Voucher specimens for species were deposited in the herbarium of Warsaw University (WA). The datasets used and analysed during the current study are available from the corresponding author upon reasonable request.

\section{Declarations}

\section{Ethics approval and consent to participate}

The methods of obtaining data during fieldwork followed guidelines set by the International Society of Ethnobiology Code of Ethics and the GDPR of the European Union and adhered to local traditions for such research. Free prior oral informed consent was obtained from all study participants. No ethical committee permits were required.

\section{Consent for publication}

Free prior oral informed consent was obtained from all study participants present in the images.

\section{Competing interests}

The authors declare that they have no competing interests.

\section{Author details}

${ }^{1}$ Ecology and Conservation Biology, Institute of Plant Sciences, University of Regensburg, Universitätsstr. 31, 93053 Regensburg, Germany. ${ }^{2}$ University of Applied Forest Sciences, Schadenweilerhof, 72108 Rottenburg am Neckar, Germany. ${ }^{3}$ Centre for Ecological Research, Institute of Ecology and Botany, Vácrátót 2163, Hungary. ${ }^{4}$ Institute of Biology and Biotechnology, University of Rzeszów, ul. Pigonia 1, 35-310 Rzeszów, Poland.

Received: 20 October 2021 Accepted: 7 February 2022 Published online: 22 February 2022

\section{References}

1. Meilleur B. Alluetain ethnoecology and traditional economy: the procurement and production of plant resources in the Northern French Alps. Doctoral thesis. University of Washington; 1986.

2. Pettersson B, Svanberg I, Tunon H. Människan och naturen: etnobiologi i Sverige. Stockholm: Wahlström \& Widstrand; 2001.
3. Mustonen T. Oral histories as a baseline of landscape restoration-comanagement and watershed knowledge in Jukajoki River. Fennia. 2013. https://doi.org/10.11143/7637.

4. Babai D, Molnár Z. Small-scale traditional management of highly species-rich grasslands in the Carpathians. Agr Ecosyst Environ. 2014;182:123-30. https://doi.org/10.1016/j.agee.2013.08.018.

5. Pawera L, Łuczaj Ł, Pieroni A, Polesny Z. Traditional plant knowledge in the white carpathians: ethnobotany of wild food plants and crop wild relatives in the Czech Republic. Hum Ecol. 2017:45:655-71. https://doi. org/10.1007/s10745-017-9938-X.

6. Varga A, Molnár Z, Biró M, Demeter L, Gellény K, Miókovics E, et al. Changing year-round habitat use of extensively grazing cattle, sheep and pigs in East-Central Europe between 1940 and 2014: Consequences for conservation and policy. Agr Ecosyst Environ 2016;234:142-53. https://doi.org/10.1016/j.agee.2016.05.018.

7. Posey DA. Indigenous ecological knowledge and the development of the Amazon. 225th ed. Boulder: Westview Press; 1983.

8. Hunn ES. N'ch'i-Wana, "The Big River": Mid-Columbia Indians and their land. Washington: University of Washington Press; 1990.

9. Turner NJ, Ignace MB, Ignace R. Traditional ecological knowledge and wisdom of aboriginal peoples in British Columbia. Ecol Appl. 2000;10:1275-87.

10. Menzies CR. Traditional ecological knowledge and natural resource management. Lincoln: University of Nebraska Press; 2006.

11. Hunn E. What is traditional ecological knowledge. In: Traditional ecological knowledge. Wisdom for sustainable development. 1993.

12. Berkes F. Sacred ecology. Milton Park: Routledge; 2017.

13. Berkes F, Turner NJ. Knowledge, learning and the evolution of conservation practice for social-ecological system resilience. Hum Ecol. 2006;34:479-94. https://doi.org/10.1007/s10745-006-9008-2.

14. Toledo VM. What is ethnoecology? Origins, scope and implications of a rising discipline. Ethnoecologica. 1992;1:5-21.

15. Nazarea VD. Ethnoecology: situated knowledgelocated lives. Tucson: University of Arizona Press; 1999.

16. Hunn E. Ethnobiology in four phases. J Ethnobiol. 2007;27:1-10. https:// doi.org/10.2993/0278-0771(2007)27[1:EIFP]2.0.CO;2.

17. Fischer $\mathrm{J}$, Hartel T, Kuemmerle T. Conservation policy in traditional farming landscapes. Conserv Lett. 2012;5:167-75.

18. Molnár Z, Bartha S, Babai D. Traditional ecological knowledge as a concept and data source for historical ecology, vegetation science and conservation biology: a Hungarian perspective. In: Szabó P, Hedl R, editors. Human nature. Studies in historical ecology and environmental history. Brno: Institute of Botany of the ASCR; 2008. p. 14-27.

19. Poschlod P, Kiefer S, Tränkle U, Fischer S, Bonn S. Plant species richness in calcareous grasslands as affected by dispersability in space and time. Appl Veg Sci. 1998;1:75-91.

20. Poschlod P, Wallis De Vries MF. The historical and socioeconomic perspective of calcareous grasslands-lessons from the distant and recent past. Biol Conserv. 2002;104:361-76.

21. Niedrist G, Tasser E, Lüth C, Dalla Via J, Tappeiner U. Plant diversity declines with recent land use changes in European Alps. Plant Ecol. 2009;202:195-210.

22. Fernández-Giménez ME, Estaque FF. Pyrenean pastoralists' ecological knowledge: documentation and application to natural resource management and adaptation. Hum Ecol. 2012;40:287-300.

23. Godwin H. Fenland: its ancient past and uncertain future. Cambridge: Cambridge University Press; 1978.

24. Poschlod P. Moore in Oberschwaben. Entstehung, Kulturgeschichte und Gedanken zur Zukunft. In (Hrsg. Konold, W.): Naturlandschaft-Kulturlandschaft. Landsberg: Ecomed. 1996:161-84.

25. Burnside NG, Joyce CB, Puurmann E, Scott DM. Use of vegetation classification and plant indicators to assess grazing abandonment in Estonian coastal wetlands. J Veg Sci. 2007;18:645-54.

26. Gugić G. Managing sustainability in conditions of change and unpredictability, the living landscape and floodplain ecosystem of the central Sava river basin. Krapje: Lonjsko Polje Nature Park Public Service; 2009.

27. Tucakov M. Tamis River Valley-dynamic floodplain. 2011.

28. Gómez-Baggethun E, Reyes-García V, Olsson P, Montes C. Traditional ecological knowledge and community resilience to environmental extremes: a case study in Doñana. SW Spain Global Environ Change. 2012;22:640-50. https://doi.org/10.1016/j.gloenvcha.2012.02.005. 
29. Demeter L. Biodiversity and Ecosystem Services of Hardwood Floodplain Forests: past, present and future from the perspective of local communities in West Ukraine. In: Roué M, Molnár Z, editors. Knowing our lands and resources: indigenous and local knowledge of biodiversity and ecosystem services in Europe and Central Asia. Paris: UNESCO Publishing; 2017.

30. Biró M, Molnár Z, Öllerer K, Lengyel A, Ulicsni V, Szabados K, et al. Conservation and herding co-benefit from traditional extensive wetland grazing. Agr Ecosyst Environ. 2020;300: 106983. https://doi.org/10 1016/j.agee.2020.106983.

31. Cook HF, Moorby H. English marshlands reclaimed for grazing: a review of the physical environment. J Environ Manage. 1993;38:55-72.

32. Middleton $B A$, Holsten $B$, van Diggelen R. Biodiversity management of fens and fen meadows by grazing, cutting and burning. Appl Veg Sci. 2006;9:307. https://doi.org/10.1658/1402-2001 (2006)9[307:BMOFAF]2.0. $\mathrm{CO} ; 2$

33. Poschlod P. Geschichte der Kulturlandschaft. Stuttgart: Ulmer; 2015.

34. Biró M, Molnár Z, Babai D, Dénes A, Fehér A, Barta S, et al. Reviewing historical traditional knowledge for innovative conservation management: a re-evaluation of wetland grazing. Sci Total Environ. 2019;666:1114-25. https://doi.org/10.1016/j.scitotenv.2019.02.292.

35. Molnár Z, Babai D, Varga A, Demeter L, Öllerer K. Messages relevant in East-Central and Eastern Europe related to traditional, indigenous and local knowledge in the Global, and the Europe and Central Asia Assessments of IPBES. Természetvédelmi Közlemények. 2019:157-76. (in Hungarian and English)

36. Posey DA, Balée WL. Resource management in Amazonia: indigenous and folk strategies. Bronx: New York Botanical Garden; 1989.

37. Gadgil M, Berkes F, Folke C. Indigenous knowledge for biodiversity conservation. Ambio. 1993;22:151-6.

38. Berkes F, Colding J, Folke C. Rediscovery of traditional ecological knowledge as adaptive management. Ecol Appl. 2000;10:1251-62.

39. Huntington HP. Using traditional ecological knowledge in science: methods and applications. Ecol Appl. 2000;10:1270-4. https://doi.org/ 10.2307/2641282

40. Moller H, Berkes F, Lyver POB, Kislalioglu M. Combining science and traditional ecological knowledge: monitoring populations for comanagement. E\&S. 2004;9:2.

41. Charnley S, Fischer AP, Jones ET. Integrating traditional and local ecological knowledge into forest biodiversity conservation in the Pacific Northwest. For Ecol Manage. 2007;246:14-28. https://doi.org/10.1016/j. foreco.2007.03.047.

42. Ballard HL, Fernandez-Gimenez ME, Sturtevant VE. Integration of local ecological knowledge and conventional science: a study of seven community-based forestry organizations in the USA. E\&S. 2008. https:// doi.org/10.5751/ES-02594-130237.

43. Pyke M, Toussaint S, Close P, Dobbs R, Davey I, George K, et al. Wetlands need people: a framework for understanding and promoting Australian indigenous wetland management. E\&S. 2018;23:43.

44. Vermeer JG, Joosten JHJ. Conservation and management of bog and fen reserves in the Netherlands. In: Verhoeven JTA, editor. Fens and bogs in the Netherlands. 1st ed. Dordrecht: Springer; 1992. p. 433-78.

45. Bignal EM, McCracken DI. Low-intensity farming systems in the conservation of the countryside. J Appl Ecol. 1996;33:413-24.

46. Poschlod P, Bakker JP, Kahmen S. Changing land use and its impact on biodiversity. Basic Appl Ecol. 2005;6:93-8. https://doi.org/10.1016/j. baae.2004.12.001.

47. Molnár Z, Kis J, Vadász C, Papp L, Sándor I, Béres S, et al. Common and conflicting objectives and practices of herders and conservation managers: the need for a conservation herder. Ecosyst Health Sustain. 2016;2: e01215. https://doi.org/10.1002/ehs2.1215.

48. Öllerer K. The ground vegetation management of wood-pastures in Romania-insights in the past for conservation management in the future. Appl Ecol Environ Res. 2014;12:549-62.

49. Sutherland WJ. Openness in management. Nature. 2002;418:834-5.

50. Poschlod P. The origin and development of the central European manmade landscape, habitat and species diversity as affected by climate and its changes-a review. Interdiscip Archaeol Nat Sci Archaeol. 2015;6:197-221.

51. Birks HH, Birks HJB, Kaland PE, Moe D. The cultural landscape: past, present and future. Cambridge: Cambridge University Press; 1988.
52. Lenzin $\mathrm{H}$. Vegetationsveränderungen durch Nutzungsaufgabe und ihre ästhetischen Konsequenzen: vegetationskundliche Untersuchungen in einer verbrachenden Borstgraswiese in der obersubalpinen Stufe der Tessiner Alpen. Flück-Wirth; 1995.

53. Rotherham ID. The implications of perceptions and cultural knowledge loss for the management of wooded landscapes: a UK case-study. For Ecol Manage. 2007;249:100-15. https://doi.org/10.1016/j.foreco.2007. 05.030.

54. Babai D, Tóth A, Szentirmai I, Biró M, Máté A, Demeter L, et al. Do conservation and agri-environmental regulations effectively support traditional small-scale farming in East-Central European cultural landscapes? Biodivers Conserv. 2015;24:3305-27. https://doi.org/10.1007/ s10531-015-0971-z.

55. Biró É, Babai D, Bódis J, Molnár Z. Lack of knowledge or loss of knowledge? Traditional ecological knowledge of population dynamics of threatened plant species in East-Central Europe. J Nat Conserv. 2014;22:318-25. https://doi.org/10.1016/j.jnc.2014.02.006.

56. Valasiuk S, Giergiczny M, Żylicz T, Klimkowska A, Angelstam P. Conservation of disappearing cultural landscape's biodiversity: are people in Belarus willing to pay for wet grassland restoration? Wetl Ecol Manage. 2018;26:943-60. https://doi.org/10.1007/s11273-018-9622-y.

57. Middleton BA. Rediscovering traditional vegetation management in preserves: trading experiences between cultures and continents. Biol Conserv. 2013;158:271-9.

58. Joyce CB, Wade PM, editors. European wet grasslands: biodiversity, management, and restoration. Chichester: Wiley; 1998.

59. Joosten H, Clarke D. Wise use of mires and peatlands: background and principles including a framework for decision-making. Totnes: International Mire Conservation Group [u.a.]; 2002.

60. Poschlod P, Baumann A, Karlik P. Origin and development of grasslands in Central Europe. In: Veen P, Jefferson R, Smidt J de, van der Straaten J, editors. Grasslands in Europe: of high nature value. Zeist: KNNV Publishing; 2009. p. 15-25.

61. van Diggelen R, Middleton B, Bakker J, Grootjans A, Wassen M. Fens and floodplains of the temperate zone: present status, threats, conservation and restoration. Appl Veg Sci. 2006;9:157-62. https://doi.org/10.1111/j. 1654-109X.2006.tb00664.x.

62. Kotowski W, Piórkowski H, editors. Competition and succession affecting vegetation structure in riparian environments: Implications for nature management; 2003.

63. Rosenthal G. Secondary succession in a fallow central European wet grassland. Flora - Morphol Distrib Funct Ecol Plants. 2010;205:153-60. https://doi.org/10.1016/j.flora.2009.02.003.

64. Fawzi NA-M, Goodwin KP, Mahdi BA, Stevens ML. Effects of Mesopotamian Marsh (Iraq) desiccation on the cultural knowledge and livelihood of Marsh Arab women. Ecosyst Health Sustain. 2016;2:e01207.

65. Middleton BA. Broken connections of wetland cultural knowledge. Ecosyst Health Sustain. 2016;2:e01223.

66. de Klerk P, Joosten H. How ancient cultures perceived mires and wetlands (3000 BCE-500 CE): an introduction. IMCG Bull. 2019:4-15.

67. Reyes-García V, Broesch J, Calvet-Mir L, Fuentes-Peláez N, McDade TW, Parsa S, et al. Cultural transmission of ethnobotanical knowledge and skills: an empirical analysis from an Amerindian society. Evol Hum Behav. 2009;30:274-85.

68. Fischer M, Wipf S. Effect of low-intensity grazing on the species-rich vegetation of traditionally mown subalpine meadows. Biol Conserv. 2002:104:1-11.

69. Bißdorf C, editor. Editorial: LUBW Landesanstalt für Umwelt BadenWürttemberg; 2021.

70. Poschlod P. Grundwassermoore in der Kulturlandschaft-Nutzungsgeschichte, Schutz-und Entwicklungsstrategien. Veröff Projekt Angewandte Ökologie. 1997;24:325-46.

71. Kotowski W, Jabłońska E, Bartoszuk H. Conservation management in fens: do large tracked mowers impact functional plant diversity? Biol Conserv. 2013;167:292-7. https://doi.org/10.1016/j.biocon.2013.08.021.

72. Okruszko H. Wetlands of the Biebrza valley, their value and future management. Wetlands of the Biebrza valley, their value and future management. 1990.

73. Bartoszuk H, Kotowski W. Large wetlands of the Biebrza Valley, Poland. In: Veen P, Jefferson R, de Smidt J, van der Straaten J, editors. Grasslands in Europe. Utrecht: KNNV Publishing; 2009. p. 84-93. 
74. Oświt J. Warunki rozwoju torfowisk w dolinie dolnej Biebrzy na tle stosunków wodnych. 143rd ed.; 1973.

75. Matuszkiewicz AJ, Głowacka I, Jakubowski W, Kamiński J, Myśliński G, Sobczyński L. Plan ochrony Biebrzańskiego Parku Narodowego. Operat: Ochrona lądowych ekosystemów nieleśnych. Maszynopis. NFOŚiGW, BPN, Warszawa. 2000.

76. Gotkiewicz W, Mickiewicz B. The realization of the agri-environmental management scheme in the area of NATURA 2000 in the Valley of Biebrza River. JARD 2015. https://doi.org/10.17306/JARD.2015.69

77. Gloger Z. Dolinami rzek: Opis podróży wzdłuż Niemna, Wisły, Bugu i Biebrzy. Warszawa: Nakład Frdynanda Hösicka; 1903.

78. Kiryło H. Wpływ środowiska przyrodniczego na wybrane zagadnienia kulturowe występujące na terenie Kotliny Biebrzańskiej. Master thesis; 1988.

79. Górniak A. Klimat województwa podlaskiego. Białystok; 2000.

80. Churski T, Szuniewicz J. Gleby hydrogeniczne i ich właściwości fizyczno-wodne w Pradolinie Biebrzy. Zeszyty Problemowe Postępów Nauk Rolniczych. 1991;372.

81. Wheeler BD, Proctor MCF. Ecological gradients, subdivisions and terminology of north-west European mires. J Ecol. 2000:88:187-203.

82. Łowmiański H. Studia nad początkami społeczeństwa i państwa litewskiego. Tom I. Wilno; 1932.

83. Kondracki J. Polska północno-wschodnia. Warszawa: Państwowe Wydawnictwo Naukowe; 1972.

84. Kamiński A. Pogranicze polsko-rusko-jaćwieskie między Biebrzą a Narwią. Rocznik Białostocki. 1963:5-42.

85. Wiśniewski J. Rozwój osadnictwa na pograniczu polsko-ruskolitewskim od końca XIV do połowy XVII wieku. Acta Baltico-Slavica. 1964:115-36.

86. Szumski J. Uwłaszczenie chłopów w północno-wschodnie j części Królestwa Polskiego 1846-1871. Białystok: Archiwum Państwowe w Białymstoku; 2002.

87. Wiśniewski J. Dzieje osadnictwa w powiecie grajewskim do połowy XVI w. [History of the Settlement in Grajewo County until the Midsixteenth Century]. In: Gnatowski M, Majecki H, editors. Studia i materiały do dziejów powiatu grajewskiego [Studies and Materials for the History of the Grajewo County]. Tom I. Warsaw; 1975.

88. Bilska-Wodecka E, Matykowski R. Struktura wyznaniowa województwa podlaskiego. In: Świątek D, Bednarek M, Siłka P, editors. Polskie Towarzystwo Geograficzne. 36th ed. Warszawa; 2008. p. 21-27.

89. Wassen MJ, Okruszko T, Kardel I, Chormanski J, Swiatek D, Mioduszewski W, et al. Eco-hydrological functioning of the Biebrza wetlands: lessons for the conservation and restoration of deteriorated wetlands. In: Bobbink R, Beltman B, Verhoeven JTA, Whigham DF, editors., et al., Wetlands: functioning, biodiversity conservation, and restoration. Berlin: Springer; 2007. p. 285-310.

90. Banaszuk H. Użytki zielone i gospodarka łąkowa w Dolinie Biebrzy. Zeszyty Problemowe Postępów Nauk Rolniczych. 1991;372.

91. Okruszko H. Przyrodniczo-gospodarcza waloryzacja pradoliny Biebrzy jako podstawa jej ochrony i zagospodarowania. Ośr. Bad. Nauk. Białystok. Nauka i Praktyka. 1986:5-134.

92. Wojciechowska-Solis J. Assessment of the economic development of regions in Poland using multidimensional comparative analysis. Economic and Social Development: Book of Proceedings. 2018:121-30.

93. Hirszfeld Z, Kaczmarczyk P. Współczesne migracje zagraniczne ludności Podlasia. Prace Migracyjne. 2000;30.

94. Oświt J. Strefowy układ zbiorowisk roślinnych jako odzwierciedlenie stosunków wodnych w dolinie dolnej Biebrzy. Zeszyty Problemowe Postępów Nauk Rolniczych. 1968;83:217-32.

95. Oświt J. Warunki rozwoju torfowisk w dolinie dolnej Biebrzy na tle stosunków wodnych [PhD Thesis]. Falenty koło Warszawy: Intytut Melioracji i Użytków Zielonych; 1970.

96. Pałczyński A. Bagna Jaćwieskie: Pradolina Biebrzy. Warszawa: Państwowe Wydawnictwo Naukowe; 1975.

97. Albuquerque UP, Cruz da Cunha LVF, de Lucena RFP, Alves RRN. Methods and techniques in ethnobiology and ethnoecology. New York, NY: Springer; 2014.

98. Berlin B. Ethnobiological classification: principles of categorization of plants and animals in traditional societies. Princeton: Princeton University Press; 1992
99. Brown CH. Language and living things: Uniformities in folk classification and naming. New Brunswick: Rutgers University Press; 1984.

100. Oświt J. Wyniki badań glebowo-florystycznych w dolinie Biebrzy dolnej. Warszawa: Centralne Biuro Studiów i Projektów Wodno-Melioracyjnych; 1965.

101. Shillcock RDA. Portrait of a Living Marsh: 32 International Artists Visit Northeast Poland. Wormer: Inmerc BV; 1993.

102. Molnár Z. Perception and management of spatio-temporal pasture heterogeneity by Hungarian herders. Rangel Ecol Manage. 2014;67:107-18. https://doi.org/10.2111/REM-D-13-00082.1.

103. Fernandez-Gimenez ME. The role of mongolian nomadic pastoralists' ecological knowledge in rangeland management. Ecol Appl. 2000:10:1318-26.

104. Molnár Z, Szabados K, Kiš A, Marinkov J, Demeter L, Biró M, et al. Preserving for the future the-once widespread but now vanishing - knowledge on traditional pig grazing in forests and marshes (Sava-Bosut floodplain, Serbia). J Ethnobiol Ethnomed. 2021;17:1-30.

105. Prawdzic M. O łakkach: Jak się z niemi obchodzić, aby mieć korzyści największe. Dla rolników. Warszawa: Księgarnia Krajowa K. Prószyńskiego; 1899.

106. Kluk K. Dykcyonarz roślinny, w którym podług układu Linneusza są opisane rośliny nietylko kraiowe dzikie, pożyteczne, albo szkodliwe... ale oraz i cudzoziemskie..., ich zdatności lekarskie, ekonomiczne, dla ludzi, koni... z przedzaiącym wykładem słów botanicznych, i kilkokrotnym na końcu reiestrem. Warszawa: Drukarnia Xsięży Piarów; 1805.

107. Babai D, Molnár Z. Multidimensionality and scale in a landscape ethnoecological partitioning of a mountainous landscape (Gyimes, Eastern Carpathians, Romania). J Ethnobiol Ethnomed. 2013;9(1):1-21.

108. Johnson LM. "A place that's good," Gitksan landscape perception and ethnoecology. Hum Ecol. 2000;28:301-25. https://doi.org/10.1023/A: 1007076221799.

109. Berezowski T, Wassen M, Szatyłowicz J, Chormański J, Ignar S, Batelaan $\mathrm{O}$, Okruszko T. Wetlands in flux: looking for the drivers in a central European case. Wetl Ecol Manage. 2018;26:849-63.

110. Łuczaj $Ł$. Changes in assumption day herbal bouquets in Poland: a nineteenth century study revisited 1. Econ Bot. 2011;65:66-75.

111. Łuczaj Ł. A relic of medieval folklore: Corpus Christi Octave herbal wreaths in Poland and their relationship with the local pharmacopoeia. J Ethnopharmacol. 2012;142:228-40

112. Truus $L$, Tõnisson $A$. The ecology of floodplain grasslands in Estonia. In: Joyce CB, Wade PM, editors. European wet grasslands: biodiversity, management and restoration. Chichester: Wiley; 1998 p. 49-60.

113. Ellenberg $\mathrm{H}$. Vegetation Mitteleuropas mit den Alpen in ökologischer, dynamischer und historischer Sicht. 5th ed. Stuttgart: Ulmer; 1996.

114. Pokropek M. Etnografia: Materialna kultura ludowa Polski na tle porównawczym. Warszawa: PWN; 2019.

115. Poschlod P, Schneider-Jacoby M, Köstermeyer H, Hill BT, Beinlich B. Does large-scale, multi-species pasturing maintain high biodiversity with rare and endangered species? — the Sava floodplain case study. In: Redecker B, Härdtle W, Finck P, Riecken U, Schröder E, editors. Pasture landscapes and nature conservation. Springer: Berlin; 2002. p. 367-78.

116. Matus I. Lud nadnarwiański. Białystok; 2000.

117. Stammel B, Kiehl K, Pfadenhauer J. Alternative management on fens: response of vegetation to grazing and mowing. Appl Veg Sci. 2003:6:245-54.

118. Budka M, Marczakiewicz P, Lachmann L, Krogulec J. Plan zarządzania dla obszaru Biebrzański Park Narodowy:W ramach projektu: „Ochrona wodniczki w Polsce i w Niemczech" (nr proj. LIFE05 NAT/PL/000101) finansowanego z funduszu UE LIFE-Nature. Biebrzański Park Narodowy; 2003.

119. Bartoszuk H, Dembek W, Dobrzyńska N, Marczakiewicz P, Kołomyjska I, Liro A, et al. Perspektywy wdrażania programów rolnośrodowiskowych w Polsce na przykładzie Doliny Biebrzy [Prespectives on implementation of agri-environmental schemes in Poland —an example from Biebrza Valley]. Warszawa; 2004

120. Mirosław-Świątek D, Marcinkowski P, Kochanek K, Wassen MJ. The impact of climate change on flow conditions and wetland ecosystems in the Lower Biebrza River (Poland). PeerJ. 2020;8: e9778. https://doi. org/10.7717/peerj.9778.

121. Klimkowska A. Peatland fires on Biebrza marshes, Poland. Int For Fire News. 2004;30:77-70. 
122. Kloskowski J, Krogulec J. Habitat selection of Aquatic Warbler Acrocephalus paludicola in Poland: consequences for conservation of the breeding areas. VOGELWELT-BERLIN-. 1999;120:113-20.

\section{Publisher's Note}

Springer Nature remains neutral with regard to jurisdictional claims in published maps and institutional affiliations.

- fast, convenient online submission

- thorough peer review by experienced researchers in your field

- rapid publication on acceptance

- support for research data, including large and complex data types

- gold Open Access which fosters wider collaboration and increased citations

- maximum visibility for your research: over $100 \mathrm{M}$ website views per year

At BMC, research is always in progress.

Learn more biomedcentral.com/submissions 